\title{
Adaptive approach-based assessment of a heritage residential complex in southern Spain for improving comfort and energy efficiency through passive strategies: a study based on a monitored flat
}

\author{
Teresa Blázquez a, *, Simone Ferrari ${ }^{\text {b }}$, Rafael Suárez a ${ }^{\text {a Juan José Sendra a }}$ \\ ${ }^{a}$ Instituto Universitario de Arquitectura y Ciencias de la Construcción, Escuela Técnica Superior de Arquitectura, Universidad de Sevilla, \\ Av. de Reina Mercedes, 2, 41012 Sevilla, Spain \\ ${ }^{b}$ Department of Architecture, Built Environment and Construction Engineering (ABC), Politecnico di Milano, via Bonardi 9, 20133 Milano, \\ Italy
}

\begin{abstract}
The energy retrofitting of residential stock is not always straightforward where heritage protected housing is concerned. In southern Europe, many examples built under the Modern Movement codes are now obsolete in terms of energy efficiency. The aim of this paper is to assess the potential for improvement of comfort conditions and energy efficiency in Mediterranean heritage residential buildings, through the incorporation of passive strategies in keeping with preserving heritage values. Long-term monitoring and field tests in representative flats of the case-study building were carried out and, focusing on a single example, adaptive comfort equations were used to assess results. The passive strategies considered are the thermal isolation of the air cavities of walls, changing window frames, optimizing window glazing, and setting up regular mechanical ventilation rates for indoor air changes. Although simulation results generally predict a better energy performance after testing retrofit strategies, the potential decrease in energy demand is more noticeable than the potential improvement in comfort conditions.
\end{abstract}

Keywords: Housing stock, heritage, monitoring, adaptive comfort, energy efficiency, passive strategies.

\section{Introduction}

About $35 \%$ of the existing residential stock in the EU is more than 50 years old [1]. Increasing the annual update rate of existing residential stock is by far one of the most effective ways to comply with the targets of European Horizon 2020 [2], preventing higher energy consumption rates derived from the impact of climate change [3]. Recent reviews to the Spanish Technical Building Code (hereafter CTE) are geared towards reducing energy demand limits and redesigning thermal envelope strategies [4]. However, when it comes to the renovation of local heritage cases, architects and building designers must ensure balanced interventions based on passive strategies that preserve aesthetic features [5]. A revision of the different criteria, procedures and decision-making to be implemented in historical buildings is included in Webb et al. [6] where retrofit interventions are seen as a way to improve the building performance according to the increasing global environmental concerns. A high proportion of the existing housing in southern Europe dates from the mid-20th century, encompassing examples of modern architecture. As a result, this housing is protected by laws designed to preserve its appearance. Housing architecture of the Modern Movement constituted a departure from earlier trends and increased awareness of issues relating to energy [7].

In order to establish the boundaries desired for this work based on the reviewed literature, Table 1 presents a summary of the methods, main results and case-study buildings found in similar works, all of which are presented clustered by topic.

\footnotetext{
* Corresponding author.

E-mail address: tblazquez@us.es (Teresa Blázquez)
} 


\begin{tabular}{|c|c|c|}
\hline $\begin{array}{l}\text { Topic 1: Energy assessment based on } \\
\text { Case-study }\end{array}$ & $\begin{array}{l}\text { nergy simulation } \\
\text { Methods }\end{array}$ & Results \\
\hline $\begin{array}{l}\text { Upper Lawn Pavilion (Great Britain) } \\
\text { [7] }\end{array}$ & Dynamic energy simulation & $\begin{array}{l}\text { Environmental design-based results reveal deficient } \\
\text { behaviour in need of updating in order to comply with } \\
\text { current standards. }\end{array}$ \\
\hline \multicolumn{3}{|c|}{ Topic 2: Energy assessment based on in situ measures } \\
\hline Case-study & Methods & Results \\
\hline Historic building (Italy) [9] & $\begin{array}{l}\text { Energy audit; infra-red } \\
\text { thermography; data collection about } \\
\text { schedule and system plant; dynamic } \\
\text { energy simulation }\end{array}$ & $\begin{array}{l}\text { New operative workflow for energy audit of historic } \\
\text { buildings; importance of non-destructive interventions and } \\
\text { post-evaluation monitoring. }\end{array}$ \\
\hline $\begin{array}{l}2005 \text { social multi-family residential } \\
\text { building (Spain) [14] }\end{array}$ & $\begin{array}{l}\text { Long-term monitoring; energy audit; } \\
\text { survey on energy habits }\end{array}$ & $\begin{array}{l}\text { Use patterns must be adapted to socio-economic profiles; } \\
\text { greater tolerance of indoor comfort conditions; less use of } \\
\text { HVAC systems than expected; individual analysis of each } \\
\text { case is crucial, as generic interventions are hard to } \\
\text { develop. }\end{array}$ \\
\hline $\begin{array}{l}10 \text { historic dwellings and a } 2004 \\
\text { housing building (France) [17] }\end{array}$ & $\begin{array}{l}\text { Long-term monitoring; infra-red } \\
\text { thermography }\end{array}$ & $\begin{array}{l}\text { Thermal characteristics of historic dwellings are different } \\
\text { from those of modern architecture; lower energy } \\
\text { consumption than the average energy consumption of } \\
\text { existing dwellings; strong thermal correlation between } \\
\text { outdoor and indoor environment. }\end{array}$ \\
\hline \multicolumn{3}{|c|}{ Topic 3: Comfort-based assessment with steady-state model } \\
\hline Case-study & Methods & Results \\
\hline $\begin{array}{l}51 \text { residential buildings: } 24 \\
\text { traditional and } 27 \text { contemporaries } \\
\text { (Libya) }[16]\end{array}$ & $\begin{array}{l}\text { Long-term monitoring; thermal } \\
\text { comfort survey and assessment } \\
\text { through PMV }\end{array}$ & $\begin{array}{l}\text { PMVs in new air-conditioned buildings provide } \\
\text { satisfactory comfort conditions according to ISO } 7730 \text {; } \\
\text { equivalent survey in old traditional buildings } \\
\text { overestimated users' discomfort. People report the } \\
\text { perception of a higher standard of thermal comfort in old } \\
\text { buildings than in new ones. }\end{array}$ \\
\hline \multicolumn{3}{|c|}{ Topic 4: Comfort-based assessment with adaptive model } \\
\hline Case-study & Methods & Results \\
\hline Social housing stock (Spain) [10] & $\begin{array}{l}\text { Long-term monitoring; dynamic } \\
\text { energy simulation; thermal comfort } \\
\text { assessment through adaptive model; } \\
\text { energy audit }\end{array}$ & $\begin{array}{l}\text { The lack of thermal insulation, efficient heating systems } \\
\text { and financial constraints of users lead to indoor conditions } \\
\text { far from comfort and exposes this housing stock to fuel } \\
\text { poverty risk. }\end{array}$ \\
\hline Office buildings (Great Britain) [11] & $\begin{array}{l}\text { Long-term monitoring; longitudinal } \\
\text { and transverse surveys of users }\end{array}$ & $\begin{array}{l}\text { Discomfort is correlated with the use of windows and fans, } \\
\text { which are used in accordance with adaptive theory; } \\
\text { opportunities for adaptation can be obtained by operating } \\
\text { local controls: windows, doors and blinds/curtains. }\end{array}$ \\
\hline Italian neighbourhood (Italy) [12] & $\begin{array}{l}\text { Energy audit; infra-red } \\
\text { thermography; long-term monitoring, } \\
\text { thermal comfort assessment; energy } \\
\text { simulation }\end{array}$ & $\begin{array}{l}\text { Handbook to educate residents about the appropriate } \\
\text { maintenance, management and use techniques for the } \\
\text { buildings they occupy. }\end{array}$ \\
\hline $\begin{array}{l}\text { pre-1945 terraced houses (Belgium) } \\
\text { [13] }\end{array}$ & $\begin{array}{l}\text { Long term monitoring; thermal } \\
\text { comfort survey to users; thermal } \\
\text { comfort assessment through adaptive } \\
\text { model }\end{array}$ & $\begin{array}{l}\text { Each house should be treated differently when designing } \\
\text { initiatives for energy efficiency improvements. Present-day } \\
\text { comfort standards do not estimate comfort conditions for } \\
\text { pre-1945 housing. }\end{array}$ \\
\hline $\begin{array}{l}\text { building with } 68 \text { social housing units } \\
\text { (Spain) [15] }\end{array}$ & $\begin{array}{l}\text { Infra-red thermography; air-tightness } \\
\text { test; solar radiation analysis; dynamic } \\
\text { energy simulation; thermal comfort } \\
\text { assessment through adaptive model }\end{array}$ & $\begin{array}{l}\text { Improving insulation in façades and windows, solar } \\
\text { protection and increasing airtightness bring about a notable } \\
\text { reduction (around 38\%) of the total demand, improving } \\
\text { indoor comfort and limiting potential energy poverty. }\end{array}$ \\
\hline \multicolumn{3}{|c|}{ Topic 5: Energy retrofit measures and decision-making } \\
\hline Case-study & Methods & Results \\
\hline 38 public buildings (Italy) [8] & Energy audit; decision-making & $\begin{array}{l}\text { This model allowed the retrofitting measures to be sorted } \\
\text { into categories, selecting those to be financed as a priority } \\
\text { taking into account the constraints in protecting } \\
\text { architectural, landscape and environmental assets. }\end{array}$ \\
\hline \multicolumn{3}{|l|}{ Topic 6: Life-cycle assessment } \\
\hline Case-study & Methods & Results \\
\hline $\begin{array}{l}\text { traditional early 20th century housing } \\
\text { building (Portugal) [18] }\end{array}$ & $\begin{array}{l}\text { Life cycle assessment of retrofit } \\
\text { strategies }\end{array}$ & $\begin{array}{l}\text { Significant energy savings can be achieved without } \\
\text { changing their historic character. Economic and } \\
\text { environmental costs can be minimized by choosing the } \\
\text { most suitable retrofit measures. }\end{array}$ \\
\hline
\end{tabular}

Table 1. Summary of reviewed literature.

With the aim of developing a balanced procedure for intervention in historic buildings, Napoli et al. [8] present a methodology to select the best strategies for implementing 210 public buildings located in the south of Italy using a "Multiple Criteria Decision Aiding" model, ELECTRE TRI-nC, which classifies the most feasible retrofitting measures by energy efficiency, financial expenditure and architectural/landscape constraints. With the pressing need to increase energy efficiency in most buildings, current energy policies often result in the 
protected stock only partially meeting the strict requirements so that heritage value may be preserved [19]. In the north of Italy, Mazzola et al. [9] assess the energy and environmental as-built conditions of a 17th'century palace for a later implementation of a retrofit designed to improve the overall performance of the building, bringing it as close as possible to energy standards.

In addition, the lack of thermal insulation and the poor quality of integrated active systems and construction materials in these buildings result in deficient energy performance and indoor environmental conditions [5]. Mediterranean multi-family dwellings built in Spain before the first regulations on thermal conditions in 1979 [20] are obsolete in terms of energy efficiency. Therefore, in this case the major challenge is not only the reduction of energy demand, but also the improvement of indoor comfort conditions, which are often far from acceptable. In fact, due to the lack of Heating, Ventilation and Air Conditioning (HVAC) systems in the majority of buildings energy waste is lower than expected [21].

Despite the existence of non HVAC-equipped buildings, current local regulations acknowledge real thermal conditions in habitable spaces on a steady-state basis [22], as is the case of the Predicted Mean Vote (PMV) and Predicted Percentage of Dissatisfied (PPD) models [23], setting stable temperature thresholds drawn from a given value of metabolic activity and clothing level for inhabitants. These models rely on the use of active systems to ensure indoor conditions remain within the comfort band [24]. In the case of naturally ventilated buildings, heating or cooling loads may be overestimated if the assessment relies on a stable development of indoor conditions. Energy demand calculation based on simulations often results in divergence between real energy performance and estimated results. An in-depth characterization of construction features and knowledge of user habits are essential for ensuring a better approach to the way a building performs [10]. In fact, choosing to open the windows, draw blinds or use fans rather than active acclimatization is strongly correlated with the user's access to these in order to avoid the feeling of discomfort [11].

Lucchi in Italy [12] and Singh in Liège, Belgium [13], carried out similar detailed research on the performance of traditional residential buildings, assessing environmental indoor conditions and analysing users' good practices and ways of adaptation through field surveys and monitoring. It was observed that users behave differently in these types of buildings, due to issues relating to culture and experience, presenting different comfort preferences. In Spain, Sendra et al. [14] carried out a constructive characterization of the existing housing stock in Andalusia and surveyed users' habits to ascertain their influence on the real performance of buildings. They conclude that each case-study building must be individually considered prior to tackling energy retrofits in order to avoid misleading results regarding real energy consumption. Energy consumption in Mediterranean residential stock is usually lower than expected, even more so in the case of social housing due to users' economic constraints. In line with this, Suárez and Fernández-Agüera [15] use a "bottom/up" strategy in a social housing building from Córdoba (Spain) to identify the most suitable strategies for the energy retrofitting of the building's thermal envelope, lowering energy consumption and improving indoor comfort conditions. Ealiwa et al. [16] carried out a comfort-based assessment of two Libyan housing buildings, a modern one (with HVAC) and a traditional (naturally ventilated) one to establish whether the general perceptions of users regarding indoor conditions are more positive in older buildings. Cantin et al. [17] studied 11 historic buildings throughout France to check the incidence of bioclimatic architecture strategies on their energy performance. Tadeu et al. [18] led research on cost-optimal retrofitting solutions on an early 20th-century building in Coimbra, by adding thermal insulation to the envelope.

Therefore, in the search for strategies for the optimization of housing building energy consumption and investment feasibility in warm climate, steady-state basis comfort standards should be carefully applied so that the desired comfort conditions are properly assessed. Alternative methods such as the adaptive models for ensuring the most suitable approaches to these cases should be considered [25].

Despite the extensive literature on the renovation of heritage buildings, few examples address the updating of residential multi-storey buildings under such architectural constraints, evaluating the improvement of thermal comfort by means of updated adaptive standards [5] (Table 1). This paper aims to assess the potential for the improvement of comfort conditions and energy efficiency in heritage residential buildings in the Mediterranean climate, relying on the adaptive comfort approach and incorporating passive strategies in keeping with the preservation of the heritage values of the building. Moreover, since adaptive indices are based on the 
assumptions and outcomes of the statistical analysis of the related studies, given the absence of an adaptive index carried out for the specific context of the study reported in this paper, the two most widely recognized adaptive comfort equations have been adopted and compared to establish the gap within obtainable results.

Current Spanish standards exclude protected buildings from the scope of application, given the possibility of the retrofitting actions needed for them to comply with energy requirements not meeting the architecture's level of protection. Therefore, taking into account the architectural nature of the case-study buildings considered in this research, retrofitting actions will not aim to adjust these constructions to current standards, but rather to ensure a significant improvement in terms of indoor comfort conditions.

This work examines a heritage residential complex dating from 1955 and located in Seville, Spain. The assessment of the potential improvements has been simulated by establishing energy models based on the results of a monitoring campaign, and therefore referring to real occupancy condition.

\begin{tabular}{|llll|}
\hline Nomenclature & & & \\
$U$ & thermal transmittance & $d$ & present day \\
$U_{\text {lim }}$ & limited thermal transmittance & $\alpha$ & weight constant \\
$U_{\text {o,lim }}$ & limited thermal transmittance for openings & $T_{c o}$ & comfort or neutral temperature \\
$m_{i}$ & measured data & $T_{\text {co Lower limit }, n}$ & instant comfort temperature lower \\
$\bar{m}$ & mean of measured data & $T_{\text {co Upper limit, } n}$ & instant comfort temperature upper \\
$s_{i}$ & simulated data & $T_{o p, n}$ & instant operative temperature \\
$n$ & present day & $D D H_{H}$ & discomfort degree-hours for heating \\
$p$ & adjustable parameters & $D D H_{C}$ & discomfort degree-hours for cooling \\
$i$ & addition index & $A C M_{L l, n}$ & adaptive comfort model lower limit \\
\hline$t_{p m a(o u t)}$ & prevailing mean outdoor temperature & $A C M_{U p, n}$ & adaptive comfort model upper limit \\
$\theta_{\text {rm(ed) }}$ & running mean external temperature & $E_{\text {Heating }}$ & annual energy demand for heating \\
$T_{\text {ext,ref }}$ & outdoor reference temperature & $E_{C o o l i n g}$ & annual energy demand for cooling \\
$\theta_{\text {ed }-n}$ & daily mean outdoor temperature of n days prior & $E_{G l o b a l}$ & annual global energy demand \\
$t_{e(d-n)}$ & daily mean outdoor temperature of n days prior & & \\
\hline
\end{tabular}

\section{Materials and methods}

This paper presents a methodological approach, complementing a monitoring campaign [26] and the adjustment of energy models [27] developed in previous works. In situ measurements allow for a higher level of scientific rigour in the simulation results using field tests such as infrared thermographic analysis and air-tightness trials, together with long-term monitoring tasks [26], on two flats with authorized access and selected (Fig. 2-3) from a local heritage residential complex. Data collected from indoor conditions and simultaneous outdoor weather were used to adjust energy models to the real environmental performances of the buildings [27], which were analysed with reference to the steady-state comfort temperature range based on the Predicted Mean Vote (PMV) approach. Figure 1 shows a diagram with the main steps and hypotheses of the proposed methodology. 


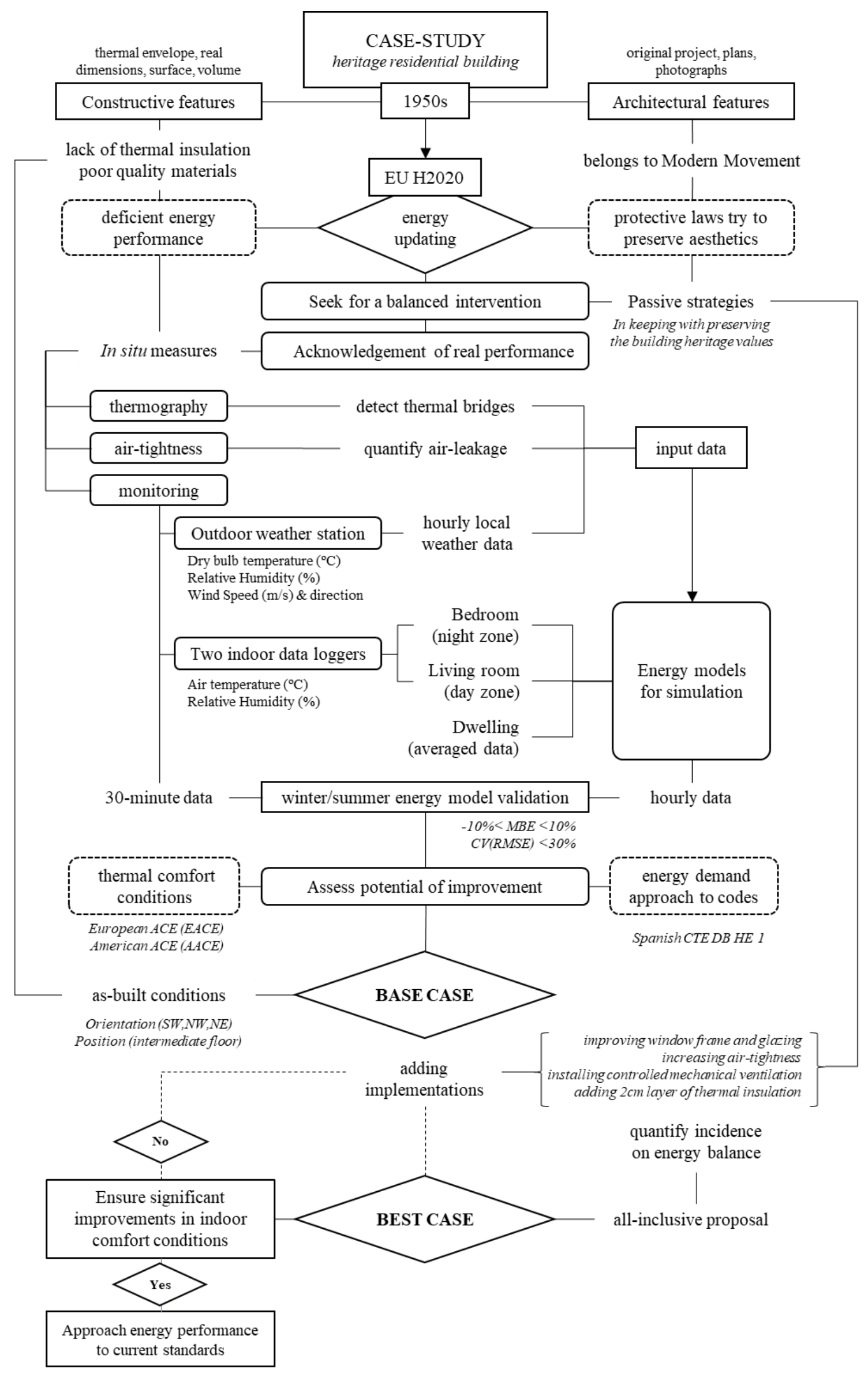

Fig. 1. Methodology flow chart. 


\subsection{Case study}

The case study reported in this paper is a heritage residential complex located in Seville (Fig. 2), a city in the south of Spain, with Mediterranean climatic conditions. Two main aspects were taken into consideration when selecting the case study building: i) it had to be of interest for environmental assessment and energy retrofitting: the group of blocks pre-dated the first Spanish regulations on energy saving in 1979 [28] and were therefore designed and built with no thermal insulation of any sort; ii) as it had to be representative of heritage values, the complex is listed in the Andalusian Institute of Heritage database [29], and is an example of the Modern Movement architecture in Andalusia [28].

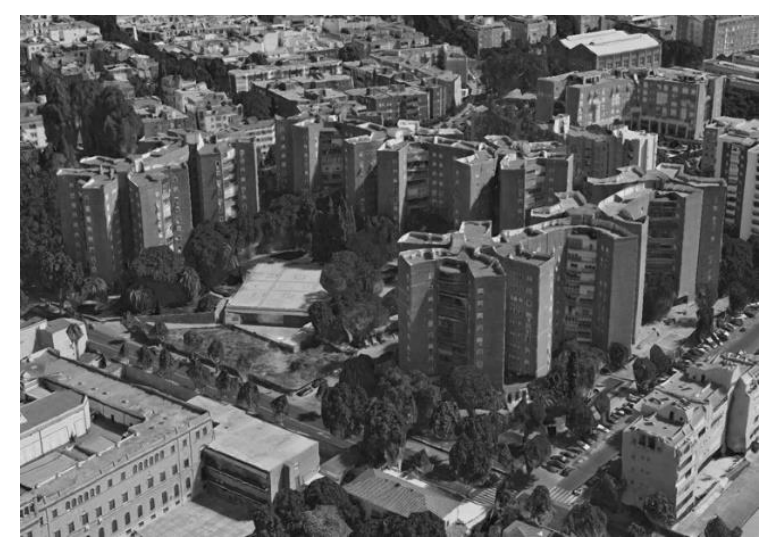

Fig. 2. Bird's eye view of the buildings

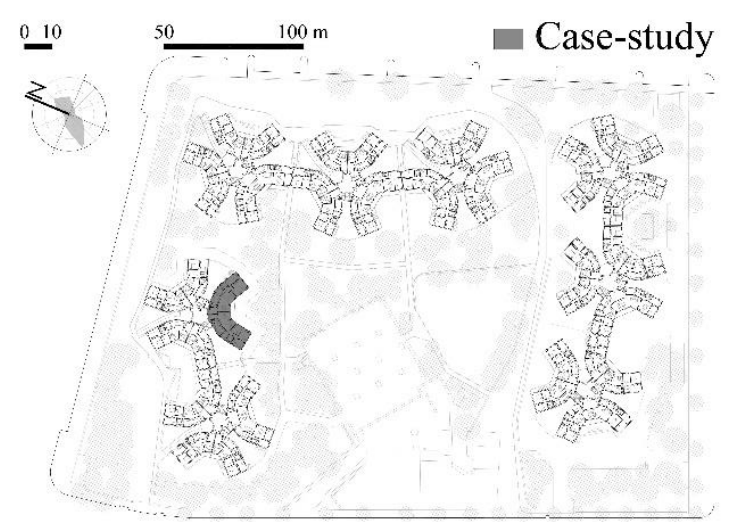

Fig. 3. Plan of the buildings with monitored flats and prevailing winds.

The residential complex was designed in the late 1950s, in keeping with the modern architectural style found in Andalusia [29], and was completed in 1963 by the brothers Medina Benjumea [30]. Of the different features correlating this work with modern architecture - for the purposes of this paper - the most important ones are (Fig. 2): i) the height of the blocks (nine storeys) and their apparently organic distribution in the area (Fig. 3) enclosing a green area for private use; ii) the global aesthetic of the buildings: the use of bare brick in the façades echoes traditional architecture; iii) the constant rhythm of ordered openings, with windows regularly set throughout the facades interrupted only by balconies in the concave areas.

The building plan is a re-interpretation of the traditional H-Block typology. The star-shaped blocks are made up of three wings linked by a central core which houses vertical communications. Ground floors accommodate commercial premises. This organization offers the housing favourable environmental characteristics, such as double exposure and cross-ventilation. In addition, the multiple orientations of the units guarantee a specific environmental performance. This fact is especially relevant in view of the Mediterranean location, where temperature fluctuations can reach extreme values in both winter and summer, with sunlight and solar radiation greatly impacting the indoor conditions of the dwellings.

Table 2 shows a comparison between estimated thermal transmittance values and mass and limit $U$ values from the Spanish code (CTE) [31]. The internal structure is made of reinforced concrete elements, without any insulation in external horizontal slabs or adjacent to spaces with no residential use. The building façade is composed of a double-layer of hollow-brick, with an inner non-ventilated air chamber. Internal partitions adjacent to common areas are made up of single layers of plastered brick. The roof is inverted and ventilated and most of the windows have undergone several modifications throughout their lifetime due to considerable air infiltration and acoustic problems. The original single-glazed windows with wooden frames and blinds were replaced with the current windows, with single- or double-glazing, aluminium frames and PVC roller blinds. 


\begin{tabular}{|c|c|c|c|c|}
\hline Element & $\begin{array}{c}\mathrm{U} \\
\left(\mathrm{W} / \mathrm{m}^{2} \mathrm{~K}\right)\end{array}$ & $\begin{array}{c}\mathrm{U}_{\lim } \\
\left(\mathrm{W} / \mathrm{m}^{2} \mathrm{~K}\right)\end{array}$ & $\begin{array}{l}\text { Deviation } \\
\quad(\%)\end{array}$ & $\begin{array}{c}\text { Mass } \\
\left(\mathrm{kg} / \mathrm{m}^{2}\right)\end{array}$ \\
\hline $\begin{array}{l}\text { Brick-faced wall, air chamber, hollow brick plastered } \\
\text { partition }\end{array}$ & 1.708 & 0.82 & 51.9 & 314.5 \\
\hline Concrete slab, sand, mortar, hydraulic tile & 1.96 & 0.52 & 73.5 & 500 \\
\hline $\begin{array}{l}\text { Hollow brick plastered wall } \\
\text { (between common areas) }\end{array}$ & 1.85 & 0.82 & 55.7 & 306 \\
\hline Opening & $\begin{array}{c}\mathrm{U} \\
\left(\mathrm{W} / \mathrm{m}^{2} \mathrm{~K}\right)\end{array}$ & $\begin{array}{c}\mathrm{U}_{\lim } \\
\left(\mathrm{W} / \mathrm{m}^{2} \mathrm{~K}\right)\end{array}$ & $\begin{array}{l}\text { Deviation } \\
(\%)\end{array}$ & $\begin{array}{l}\text { Openings } \\
(\%)\end{array}$ \\
\hline $\begin{array}{l}\text { Bedroom, double glazing } 6.6 .6 \\
\text { Metal frame (no thermal bridge breaking) }\end{array}$ & 3.9 & 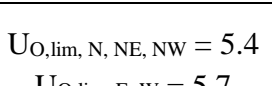 & $\begin{array}{l}-38.5 \\
-46.2\end{array}$ & 5 \\
\hline $\begin{array}{l}\text { Bedroom, single glazing } 4-6 \mathrm{~mm} \\
\text { Metal frame (no thermal bridge breaking) }\end{array}$ & 5.70 & $\mathrm{U}_{\mathrm{O}, \lim , \mathrm{S}, \mathrm{SE}, \mathrm{SW}=5.7}$ & $\begin{array}{c}18.6 \\
0\end{array}$ & 5 \\
\hline $\begin{array}{l}\text { Living room, double glazing } 6.6 .6 \\
\text { Metal frame (no thermal bridge breaking) }\end{array}$ & 3.61 & $\begin{array}{c}\text { Uo,lim, N, NE, NW }=3.8 \\
\text { Uo,lim, E, } w=4.9\end{array}$ & $\begin{array}{c}-5.3 \\
-35.8 \\
-57.9\end{array}$ & 18 \\
\hline $\begin{array}{l}\text { Living room, single glazing } 4-6 \mathrm{~mm} \\
\text { Metal frame (no thermal bridge breaking) }\end{array}$ & 5.70 & $\mathrm{U}_{\mathrm{O}, \mathrm{lim}, \mathrm{S}, \mathrm{SE}, \mathrm{SW}}=5.7$ & $\begin{array}{l}33.3 \\
14.1\end{array}$ & 18 \\
\hline
\end{tabular}

Table 2. Constructive definition of the building thermal envelope. Ulim according to CTE [31].2.2 Climatic data

The city of Seville has a Mediterranean climate with slight continental features and is identified as Csa according to the Köppen-Geiger climate classification [32], with very hot dry summers and mild and rainy winters. The average temperature is $19.2^{\circ} \mathrm{C}$, one of the highest in Europe. January is the coldest month, with an average minimum temperature of $5.7^{\circ} \mathrm{C}$, while July is the hottest, with an average maximum temperature of $36^{\circ} \mathrm{C}$. Given these high summer temperatures, Seville is one of the hottest cities in Spain, with temperatures repeatedly exceeding $40^{\circ} \mathrm{C}$ throughout the year [33].

\subsection{Field tests: Infrared thermography and Airtightness}

Thermographic images were taken to establish thermal behaviour patterns and to detect infiltration routes of possible energy losses. Infrared images were taken using a FLIR ThermaCAM B4 camera. The colour scale relying on the superficial thermal difference captured in the images highlights weak points of the thermal envelope, such as window frames, the blinds above and structural elements (framework, beams, pillars) [26]. Pressurization and depressurization trials were run with a Blower Door, following ISO 9972: 2006 protocol [34] in order to assess the impact on energy demand and indoor air quality of uncontrolled air changes through the unsealed points of the façades. The equipment was installed at the main door of the flat, and after sealing internal partitions in order to isolate the room taking part in the individual measurements, several tests were run by managing the devices from indoors. The results of the test show that the flat can be graded as middle-airtight, according to EN-ISO 52016-1:2017 [35] (Table 3). Air-change rates obtained under a $50 \mathrm{~Pa}\left(\mathrm{n}_{50}\right)$ pressurization in the flats are similar to those observed in dwellings built prior to 1979 in southern Spain [36].

\begin{tabular}{lccccc}
\hline & Dwelling A & LrA & BdA & Dwelling B & LrB \\
\hline Air leakage rate at 50 Pa: $\mathrm{V}_{50}\left(\mathrm{~m}^{3} / \mathrm{h}\right)$ & 1828 & 349 & 265 & 2371 & 569 \\
Air change rate at 50 Pa: $\mathrm{n}_{50}\left(\mathrm{~h}^{-1}\right)$ & 6.9 & 3.8 & 9.0 & 8.6 & 5.4 \\
\hline
\end{tabular}

Table 3. Air permeability test results in dwelling A, BdA (dwelling A bedroom), LrA (dwelling A living room), dwelling B and $\mathrm{LrB}$ (dwelling B living room).

\subsection{Monitoring}

The methodology and results obtained from monitoring the case-study flats have been shown in a previous work [26]. As regards active systems, the case-study buildings are not equipped with HVAC-centralized systems. Instead, the flats only have a split-heat pump and a small heater in the living room (according to the survey, in winter users prefer to use the latter), and an electric radiator in the bedroom [26]. 

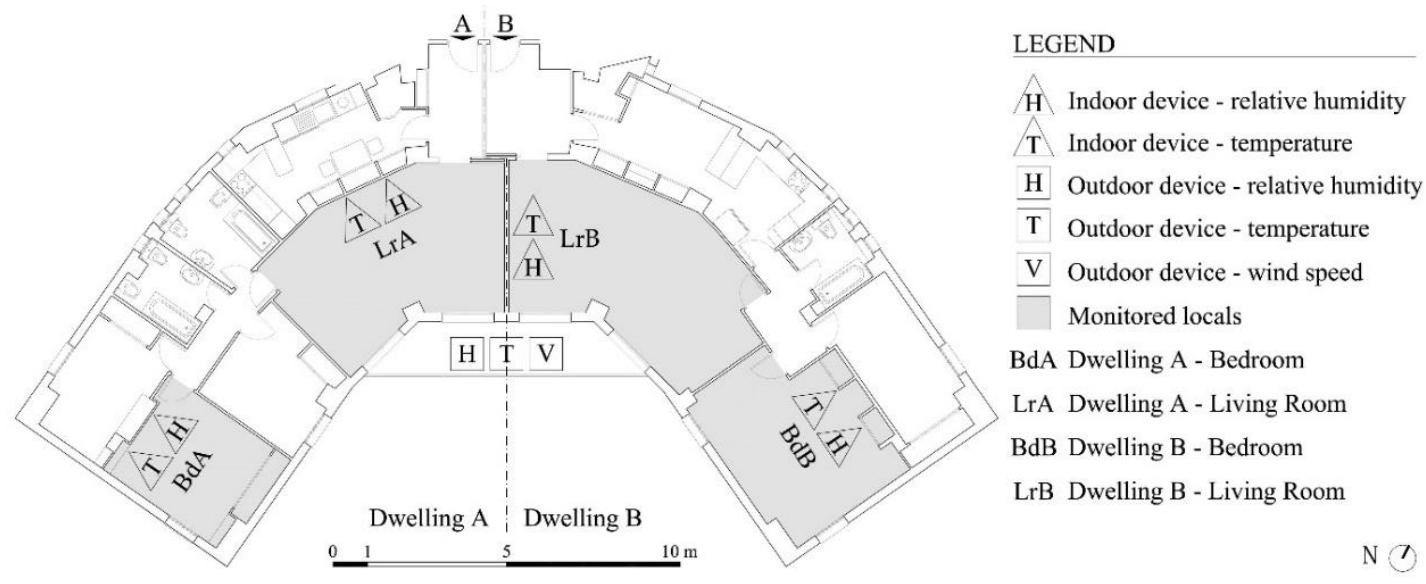

Fig. 4. Positioning of monitoring devices in case-study flats.

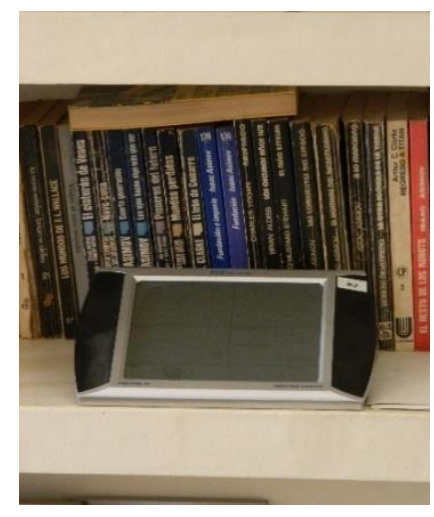

(a)

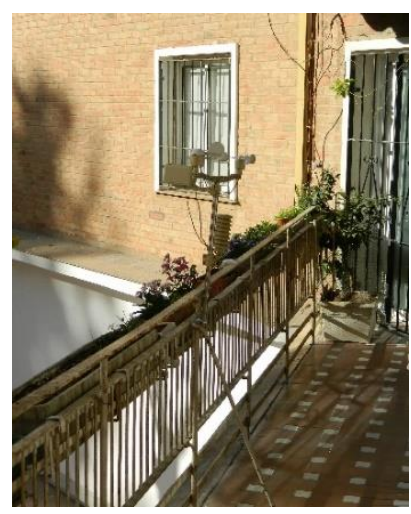

(b)

Fig. 5. Monitoring devices in case-study flats: (a) indoor data logger; (b) outdoor weather station.

A long-term monitoring campaign is suited to environmental assessments over an extended period of time [10], and facilitates the evaluation of comfort conditions using an adaptive approach, as seen in this study (Section 2.7). One of the aims of the monitoring process was participation in the calibration of the energy models that reproduce the current conditions of the case-study flats. Two dwellings ( $\mathrm{A}$ and $\mathrm{B}$ ), with a usable floor area of $102.965 \mathrm{~m}^{2}$, were chosen for this task, and bedrooms (BdA and $\mathrm{BdB}$ ) and living rooms ( $\operatorname{LrA}$ and $\mathrm{LrB}$ ) were monitored under real occupancy conditions (Fig. 4). Two data loggers were placed in each monitored room 80 $\mathrm{cm}$ high and protected from direct sun in order to record indoor parameters such as air temperature and relative humidity (Fig. 5a) (Table 4). In addition to indoor data loggers, the systems were complemented with a local weather station to record dry bulb temperature and relative humidity, as well as wind speed and direction, dew temperature, pressure and rainfall (Table 4). The weather station was placed in the balcony, protected from strong gusts of wind (Fig. 5b). As the adjustment of the energy models is done on an hourly basis, the accuracy of devices (Table 4) was considered trustworthy for collecting data at 30-minute intervals. As a result, a total of 563,328 entries were recorded. Monitoring lasted a full year from 1 April 2015 to 31 March 2016 [26], and was carried out following UNE EN ISO 7726: 2002 protocol [37].

\begin{tabular}{ccccccccc}
\hline Devices (Indoor/Outdoor) & Weather station & BdA & LrA & BdB & LrA & \multicolumn{2}{c}{ Range of measures } & Error \\
\hline & & & & & & Outdoor & Indoor & \\
\hline Air temperature & 1 & 1 & 1 & 1 & 1 & $-40-65{ }^{\circ} \mathrm{C}$ & $0-60{ }^{\circ} \mathrm{C}$ & $0.1{ }^{\circ} \mathrm{C}$ \\
Wind speed and direction & 1 & & & & & $0-180 \mathrm{~km} / \mathrm{h}$ & & \\
Relative humidity & 1 & 1 & 1 & 1 & 1 & $12-99 \%$ & $1 \%$ \\
Total & 4 & 3 & 3 & 3 & 3 & & & \\
\hline
\end{tabular}

Table 4. Summary of accuracy of installed devices in the monitored dwellings. 


\subsection{Generation and adjustment of energy models}

To date, literature about energy models calibration criteria is not standardized [38]. Adjusting predicted behaviour to the real performance of a case-study is a complex task involving many uncertain parameters which can mislead results [39]. Commonly in Mediterranean housing buildings, energy consumption is so low that most of the time indoor conditions evolve in a free-floating regime. Energy models in the present work are therefore manually tuned to ensure that indoor environmental parameters and measured ones are as close as possible. This adjustment is concentrated on the air temperature inasmuch as it will be the key parameter in the later comfort-based assessment [10].

Energy models were generated ad hoc using DesignBuilder (v.4.2.0.054) simulation software with calculation engine Energy+. The adjustment of energy models was carried out hourly, simultaneously to monitoring data collection and analysis [27], following ASHRAE Guideline 14 [40]. Results are validated both graphically (to test whether results deviate or converge) and statistically (to measure the closeness of results). Indeed, in order to verify the reliability of results, two statistical indexes were considered: The Normalized Mean Bias Error (NMBE), which measures the differences between the predicted and the measured values; and the Coefficient of Variation (CV) of the Root Mean Squared Error (RMSE), which measures the error variability of results and whether overall the model can behave similarly to reality. Both indexes were calculated following equations (1) and (2). In both equations, the value of $p$ was considered to be between 0 and 1 according to [41].

$$
\begin{gathered}
N M B E=\frac{1}{\bar{m}} \cdot \frac{\sum_{i=1}^{n}\left(m_{i}-s_{i}\right)}{n-p} \times 100(\%) \\
C V(R M S E)=\frac{1}{\bar{m}} \cdot \sqrt{\frac{\sum_{i=1}^{n}\left(m_{i}-s_{i}\right)^{2}}{n-p}} \times 100(\%)
\end{gathered}
$$

Where $m_{i}$ is the measured value at instance $n ; s_{i}$ : simulated value at instance $n ; n$ is the number of values used in the adjustment depending on the interval-basis (i.e. monthly, hourly, etc.) and $\overline{\mathrm{m}}$ is the mean of the measured values. The analysis of results should take both into account as NMBE can be subject to cancellation errors and CV(RMSE) validates the accuracy of results. For an hourly analysis, the criteria of ASHRAE Guideline 14 consider energy models to be validated if NMBE results fall within $\pm 10 \%$ and CV(RMSE) values fall below $30 \%$.

The process of fitting the predicted and the measured results began at an initial 'cell level', which required the design of two energy models, reproducing the environmental performance of the monitored rooms in each flat (living room and bedroom) as closely as possible using a simplified cell. Eventually, two different versions were produced: one for winter and one for summer. The time period for adjusting energy models to both seasonal conditions was one month (January for winter and June for summer). In order not to make energy models too complex and to avoid biased results, in both cases certain boundary conditions were examined as follows: i) energy flux was only considered throughout the outer envelope and through the floor in contact with ground floor commercial premises, while the rest of internal partitions remained adiabatic; ii) constructive definition, real orientation, floor position (Section 2.1), local climate (Section 2.2) and in situ measurements (Section 2.3) were input variables thanks to the data collected; iii) users' energy habits (handling of electric appliances and general lighting) and occupancy schedules taken from onsite surveys were included in order to incorporate user behaviour into the adjustment process.

As a step towards a second level of calibration, 'dwelling level', the energy cells were transferred to a whole flat energy model, maintaining the same boundary conditions. Indoor measured data for the whole dwelling were obtained from an arithmetic hourly mean of indoor temperature values recorded in each monitored room. This approach aimed to increase the reliability of the following energy assessments at dwelling level. 


\subsection{Simulation of energy models}

\subsubsection{Base Case energy model}

Prior to proposing energy retrofitting strategies, an environmental characterization had to be carried out for the entire building to describe the as-built conditions. To this end, an energy model named Base Case was created as a simplification of the existing building, following the star-shaped plan of the blocks, while taking into consideration two main variables, orientation and floor height. In the case of a) orientation, existing housing units were aligned in three different positions and grouped according to [31]: southeast (SE), northwest (NW) and northeast (NE) orientations. In the case of b) floor height, although the existing blocks have nine storeys each, in the Base Case, the housing units are located on the fifth floor, which is considered an intermediate representative floor of the block (IF). Infiltration rates vary with height and were therefore estimated starting from that measured in the monitored flat on the first floor.

For the hourly assessment of indoor conditions, the base-case model is run in free floating regime, whereas monthly and annual heating and cooling demands were calculated in terms of primary energy $\left(\mathrm{kWh} / \mathrm{m}^{2}\right)$, as HVAC systems must be active and are implemented in the energy model. HVAC system loads and use schedules were set according to the specific annex in CTE [31]. The analysis covered a full year. Data were clustered for the winter (21 Dec - $21 \mathrm{Mar}$ ) and summer periods (21 Jun-21 Sep).

\subsubsection{Testing the strategies: sensitivity analysis for the Base-Case and Best-Case energy models}

In order to test energy retrofitting strategies to improve energy performance of the case-study flats, a prior sensitivity analysis was necessary. The incidence of each of the actions considered for the thermal envelope was verified, including changing window joinery and glazing, controlling ventilation, and adding thermal insulation to the façades.

1. Window characterization. This strategy $\left(\mathrm{H}_{\mathrm{VG}}\right)$ studies the effect of joinery and glazing on annual energy demands, which considers variable glazing depending on window orientation. Firstly, aluminium joinery was replaced with PVC, while different types of glazing were analysed considering three main aspects: i) insulated glass units (IG units), with variable air chamber thicknesses; ii) different internal and external glass thicknesses to improve acoustic behaviour (4 mm-external and $6 \mathrm{~mm}$-internal); iii) different types of glazing, based on the placement of metal oxide layers inside the glass to enhance thermal insulation and solar control modifying the Solar Heat Gain Coefficient (SHGC) of the glazing from 0.703 (IG with two layers of Normal Clear glazing) to 0.602 (IG with an interior Low Solar Gain Low-E glazing). Different combinations of frame and glazing were assessed based on resulting U values taken from the CTE Catalogue [42]. Best options were tested on an energy model of the case-study flat to see the effect of windows in energy demand. Window glazing was changed depending on the orientation: 4.12.6 IG units and normal glazing were placed in south-oriented windows; 4.16.6 IG units and low emissive coating were placed in north-oriented ones.

2. Air-tightness and ventilation. Three different hypotheses, $\mathrm{H}_{\mathrm{V} 1}, \mathrm{H}_{\mathrm{V} 1+\mathrm{V} 2}$ and $\mathrm{H}_{\mathrm{V} 1+\mathrm{V} 2+\mathrm{R}}$, were formulated (Table 5): i) $\mathrm{H}_{\mathrm{V} 1}$ set an increase in the dwelling air-tightness, incorporating a frame with $3 \mathrm{~m} / \mathrm{h} / \mathrm{m}^{2}$ permeability under $100 \mathrm{~Pa}$, in line with UNE-EN 12207 [43]; ii) $\mathrm{H}_{\mathrm{V} 1+\mathrm{V} 2}$ foresaw controlled renewed air through a basic mechanical ventilation (MV) system, without heat recovery (HR), substituted by natural ventilation (NV) only during the night in summer, according to the Spanish CTE document [44]; iii) $\mathrm{H}_{\mathrm{V} 1+\mathrm{V} 2+\mathrm{R}}$, includes a heat recovery system (HR), with a conservative performance of $60 \%$. 


\begin{tabular}{|c|c|c|c|c|c|c|}
\hline & Infiltrations & NV & NV Schedule & MV & MV Schedule & HR \\
\hline Base-Case & $0.7 \mathrm{ACH}^{*}$ & $3.3 \mathrm{ACH}^{*}$ & $\begin{array}{l}\text { Modelled from onsite } \\
\text { survey (real user) }\end{array}$ & - & - & - \\
\hline $\mathrm{H}_{\mathrm{V} 1}$ & $0.1 \mathrm{ACH}$ & $3.3 \mathrm{ACH}^{*}$ & $\begin{array}{l}\text { Modelled from onsite } \\
\text { survey (real user) }\end{array}$ & - & - & - \\
\hline $\mathrm{H}_{\mathrm{V} 1+\mathrm{V} 2}$ & $0.1 \mathrm{ACH}$ & $4 \mathrm{ACH}$ & 0-8h (Jun-Sep) & $0.4 \mathrm{ACH}$ & $\begin{array}{l}\text { 0-24h (Oct-May) } \\
\text { 8-24h (Jun-Sep) }\end{array}$ & - \\
\hline $\mathrm{H}_{\mathrm{V} 1+\mathrm{V} 2+\mathrm{R}}$ & $0.1 \mathrm{ACH}$ & $4 \mathrm{ACH}$ & 0-8h (Jun-Sep) & $0.4 \mathrm{ACH}$ & $\begin{array}{l}\text { 0-24h (Oct-May) } \\
\text { 8-24h (Jun-Sep) }\end{array}$ & $\begin{array}{c}60 \% \\
(\text { Jan-Dec) }\end{array}$ \\
\hline
\end{tabular}

Table 5. Description of ventilation hypotheses. Natural ventilation (NV) and mechanical ventilation (MV) system, with/without heat recovery (HR).

3. Thermal insulation. Hypothesis $\mathrm{H}_{\mathrm{TI}}$ considers the implementation of external walls with thermal insulation. Given that the outer appearance of the buildings had to be preserved and the dwellings were inhabited, a nonintrusive strategy was proposed, injecting polyurethane into the wall air chamber. A useful thickness of only 2 cm was considered, based on a conservative approach, reducing the wall's U value to $1.09 \mathrm{~W} / \mathrm{m}^{2} \mathrm{~K}$.

Finally, an all-inclusive proposal, obtained from the results of sensitivity analysis, was incorporated into an energy model implemented, named Best Case. This was used to predict improvement in the overall indoor comfort conditions [45] and annual energy demand according to [31].

\subsection{Comfort-based assessment}

One of the main goals of the present study is to check whether indoor comfort conditions are bearable or are in need of optimization. The different ways to assess indoor comfort include those based on the PMV-PPD [23] on a steady-state basis, and those based on adaptive comfort theories, which state that weather shifts can have an immediate impact on the changes in indoor environmental conditions. Since case-study units do not have any HVAC systems, basing this assessment on adaptive comfort theories is the best possible way to ensure a real approach.

Based on the assumptions and outcomes of the statistical analysis of the related studies adaptive indices are characterized by different correlations between the indoor comfort temperature and the outdoor one. Therefore, in order to establish the gap within the results obtainable as applied to the context of this study, the two most widely recognized Adaptive Comfort Equations (ACEs) have been adopted and compared: ANSI/ASHRAE Standard 55 [46], hereafter AACE, and European EN 15251 Comfort Standard [47], EACE (Table 6). Both these models were drawn from field measurements and comfort surveys: the AACE was developed from the RP-884 global database [48] and the EACE was built up with the European SCATs database [49]. To ensure reliable results, both models were compared on a like-for-like basis, taking into account the acceptability range for each equation. A PPD value of 10 was selected for a consistent acceptability range of $80 \%$ in AACE, and EACE Category II.

\begin{tabular}{|c|c|c|c|c|c|}
\hline & $\mathbf{T}_{\text {ext, ref }}$ & PPD & Acceptability range & $T_{\text {ext ref }}$ applicable range & ACE \\
\hline AACE & $\overline{\overline{t_{p m a(\text { out })}}}$ & $<10$ & $80 \%\left( \pm 3.5^{\circ} \mathrm{C}\right)$ & $10^{\circ} \mathrm{C}<T_{\text {ext }, \text { ref }}<33.5^{\circ} \mathrm{C}$ & $T_{c o}=0.31 \cdot T_{\text {ext }, \text { ref }}+17.8$ \\
\hline EACE & $\theta_{r m(e d)}$ & $<10$ & Category II $\left( \pm 3{ }^{\circ} \mathrm{C}\right)$ & $\begin{array}{l}10^{\circ} \mathrm{C}^{(1)}<T_{\text {ext,ref }}<30^{\circ} \mathrm{C} \\
15^{\circ} \mathrm{C}^{(2)}<T_{\text {ext,ref }}<30{ }^{\circ} \mathrm{C}\end{array}$ & $T_{c o}=0.33 \cdot T_{\text {ext }, \text { ref }}+18.8$ \\
\hline
\end{tabular}

Table 6. ACEs considered in comfort-based assessments.

In the formulation of ACEs, the reference outdoor temperature is the independent variable and that which determines the applicability of the index to the weather of a specific location. This takes into account the influence of weather conditions in the user's thermal experience. In pursuit of more accurate results, the consideration of a monthly averaged value of outdoor temperature entailed such biased errors that researchers 
soon replaced this with a weighted daily average of the series of daily outdoor temperature values previous to the analysed day [50,51]. In its most recent revision in 2013, ASHRAE Standard 55 joined this trend [52] and proposes a prevailing mean outdoor temperature $\left(\overline{\mathrm{t}_{\mathrm{pma}(\mathrm{out})}}\right)$ (3) measuring the incidence of previous daily local climate (considering a period of more than seven days, but less than thirty), which diminishes the further apart the days are. A seven-day period was considered in this study. In European standard EN 15251, the outdoor temperature referenced is the running mean external temperature $\left(\theta_{\mathrm{rm}(\mathrm{ed})}\right)$, whose approximate equation for the seven days prior to the day analysed, is shown in (4).

$$
\begin{gathered}
\overline{t_{p m a(\text { out })}}=(1-\propto) \cdot\left[t_{e(d-1)}+\propto \cdot t_{e(d-2)}+\alpha^{2} \cdot t_{e(d-3)}+\alpha^{3} \cdot t_{e(d-4)}+\alpha^{n-1} \cdot t_{e(d-n)}\right] \\
\theta_{r m(e d)}=\frac{\left(\theta_{e d-1}+0.8 \cdot \theta_{e d-2}+0.6 \cdot \theta_{e d-3}+0.5 \cdot \theta_{e d-4}+0.4 \cdot \theta_{e d-5}+0.3 \cdot \theta_{e d-6}+0.2 \cdot \theta_{e d-7}\right)}{3.8}
\end{gathered}
$$

where $\alpha$ in equation (3) is a constant with a value between 0 and 1. ASHRAE Standard 55 sets a value of 0.6 for highly fluctuating series of outdoor daily temperature, whereas a value of 0.9 is given to the climates where daily outdoor temperature values remain stable [46].

Two different forms of assessment should be considered: i) 'temperature clouds' as a result of plotting instantaneous measurement of indoor and outdoor temperatures and comfort temperature estimated with different ACEs against the simultaneous outdoor reference temperature [53]; ii) calculation of 'discomfort degree-hours' (DDH), as the accumulated amount of differences between indoor air temperature (in the case of monitoring results), or operative temperature (in the case of simulation results), and comfort temperature values according to (5) and (6) [29]. That is to say, the amount of hours where indoor conditions are outside the comfort limits and heating or cooling loads are required:

$$
\begin{gathered}
\text { When } T_{\text {co Lower limit }, n}>T_{o p, n} \quad D D H_{H}=\sum_{i=1}^{n}\left(T_{o p, n}-A C M_{L l, n}\right) \\
\text { When } T_{\text {co Upper limit,n }}<T_{o p, n} \quad D D H_{C}=\sum_{i=1}^{n}\left(A C M_{U l, n}-T_{o p, n}\right)
\end{gathered}
$$

where $\mathrm{T}_{\text {co Lower limit,n }}$ is the resultant hourly lower limit comfort temperature through the application of an ACE over $\mathrm{T}_{\text {ext,ref }}$ hourly values; $\mathrm{T}_{\text {co Upper limit, } \mathrm{n}}$ is the resultant hourly upper limit comfort temperature by applying an ACE over $\mathrm{T}_{\text {ext,ref }}$ hourly values; $\mathrm{T}_{\mathrm{op}, \mathrm{n}}$ is the hourly operative temperature; $\mathrm{DDH}_{\mathrm{H}}$ is the total amount of discomfort degree-hours required for the use of heating; and $\mathrm{DDH}_{\mathrm{C}}$ is the total amount of discomfort degree-hours required for the use of cooling. Note that from this point on, only negative values were considered. Not only does this index measure the amount of time that the indoor conditions in the flat fall outside the comfort range, but also quantifies how big the temperature difference gets.

\section{Results}

This section shows the results from several environmental assessments in case-study units: current state indoor conditions through monitoring, current state indoor conditions through adjusted energy models and after-retrofit indoor conditions, also using energy models. In short, this approach is employed solely for the monitored flat in case-study A.

\subsection{Monitoring results}

Monitoring results in dwelling A were assessed through a comfort-based evaluation according to AACE and EACE (Section 2.7). Indoor conditions have been assessed by comparing the hourly development of monitored indoor air temperature and the simultaneous outdoor dry bulb temperature, together with a comfort temperature range obtained by applying the ACEs from Table 6. The outdoor reference temperature values to be included in the ACEs were calculated using expressions (3) and (4) and the local dry bulb temperature collected. 
An initial step consisted in the graphic analysis of monitored environmental parameters (indoor air temperature) and the simultaneous local weather data (outdoor dry bulb temperature). In order to summarize, Figures 6 and 7 present the hourly development of indoor and outdoor conditions for a summer and winter 30-day period, respectively. In both cases, indoor conditions are assessed together with the corresponding range of comfort temperature according to the ACEs considered. Figure 6 shows the hourly development of environmental parameters covering a summer period from 21 June to 21 July 2013, and the upper comfort limit set by each adaptive comfort index (6). In contrast, Figure 7 presents the hourly development of monitored results corresponding to a winter period from 21 December 2013 to 21 January 2014, as well as the lower comfort limit set by each adaptive comfort index (5). The indoor values recorded in each case show a high dependence on the local weather data, reaching values of around $30^{\circ} \mathrm{C}$ when outdoor temperatures in summer go up to $43^{\circ} \mathrm{C}$ (Fig. 6), and remaining below $19^{\circ} \mathrm{C}$ most of the time during the cold season (Fig. 7). The highly sensitive indoor conditions also show that temperature values are always at the bottom end of the lower range of comfort in winter but often greatly exceed the upper threshold during the warm season.

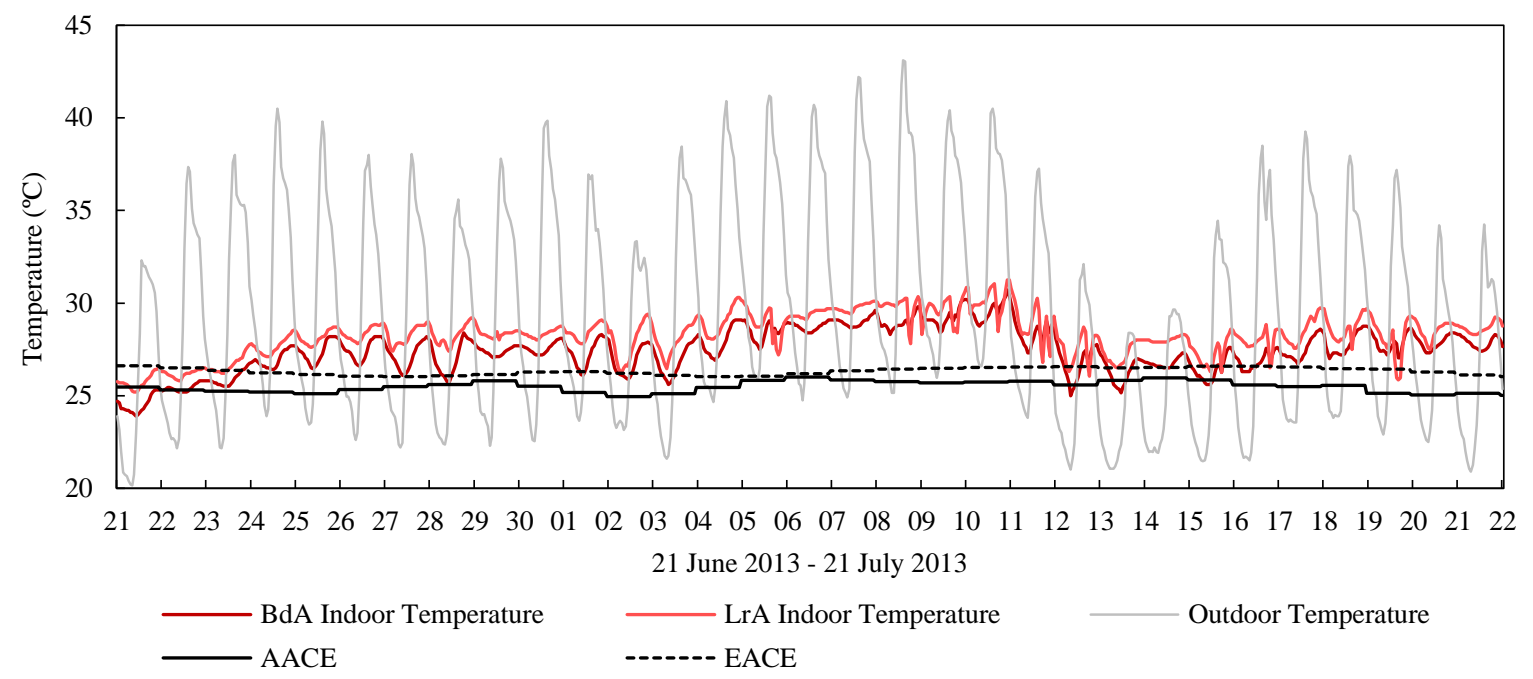

Fig. 6. Hourly air temperature evolution in BdA (dwelling A bedroom) and LrA (dwelling A living room) in summer (from 21 June 2013 to 21 July 2013) using AACE [46] and EACE [47].

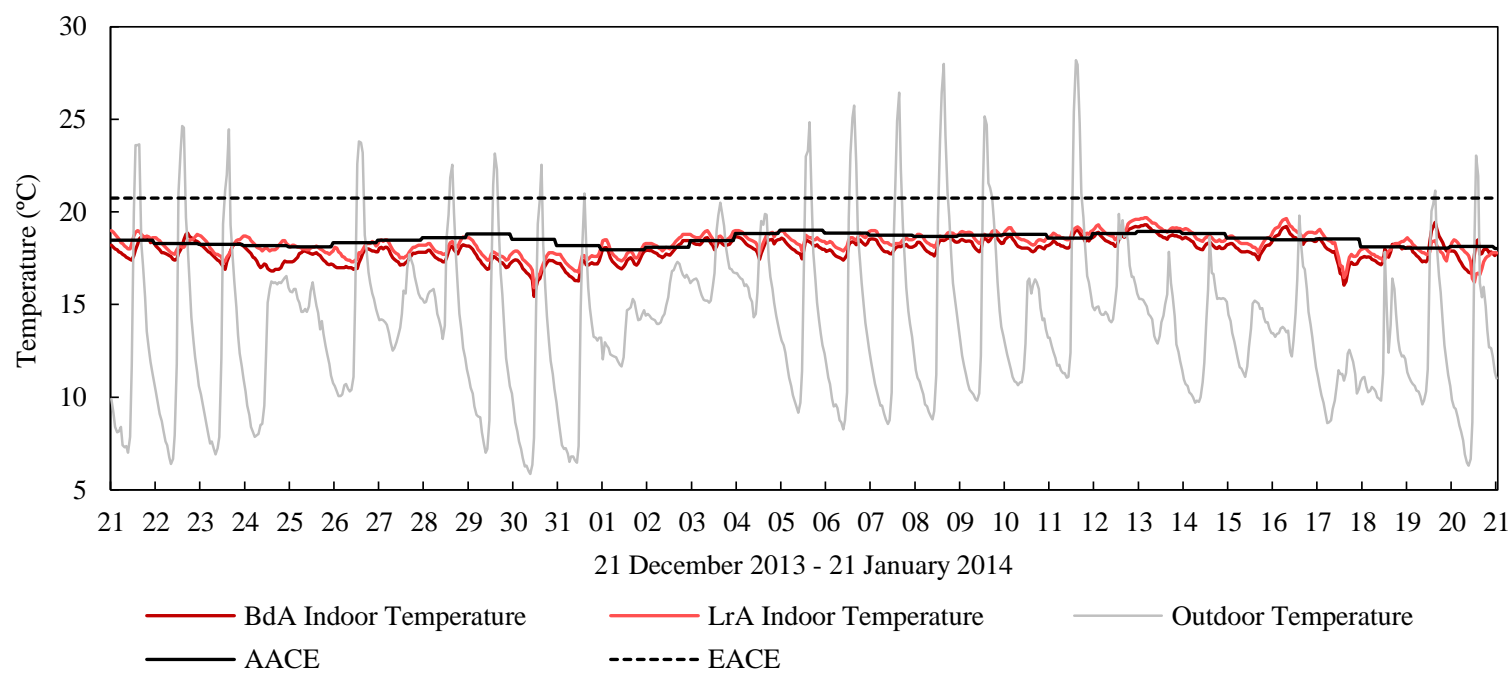

Fig. 7. Hourly air temperature evolution in BdA (dwelling A bedroom) and LrA (dwelling A living room) in winter (from 21 December 2013 to 21 January 2014) using AACE [46] and EACE [47].

In order to complement the hourly analysis, Figure 8 represents the instantaneous indoor air temperature plotted against the simultaneous outdoor temperature while it is evaluated by the aforementioned adaptive indexes. 
Winter and summer data have been clustered for analysis: Figs. 8a and 8b present the results recorded for the whole cold period, while Figs. 8c and 8d display the results for the entire warm season.

Figure 8 shows that both rooms share similar trends in both seasons. In winter, indoor conditions seem to be below comfort most of the time. The majority of indoor air temperature values recorded stayed between $16^{\circ} \mathrm{C}$ and $18{ }^{\circ} \mathrm{C}$, which would be outside the range of comfort (EACE sets a comfort temperature lower limit of 20.75 ${ }^{\circ} \mathrm{C}$ for a minimum value of outdoor reference temperature of $15^{\circ} \mathrm{C}$ ). In summer, indoor temperature values stayed below the upper comfort temperature for longer hours. From the referenced figures, the building's sensitivity to outdoor conditions can be observed when indoor temperatures increased from $30{ }^{\circ} \mathrm{C}$ to $32{ }^{\circ} \mathrm{C}$ as the simultaneous weather got warmer. Nevertheless, the fact that indoor conditions reached these temperature values while outdoor dry bulb temperatures remained lower, from $25^{\circ} \mathrm{C}$ to $30^{\circ} \mathrm{C}$, reflects overheating processes so that heating dissipation mechanisms become necessary. The combination of a deficient thermal envelope and the sporadic use of electric devices which are highly costly for users, explains why the dwelling could not maintain stable indoor conditions.

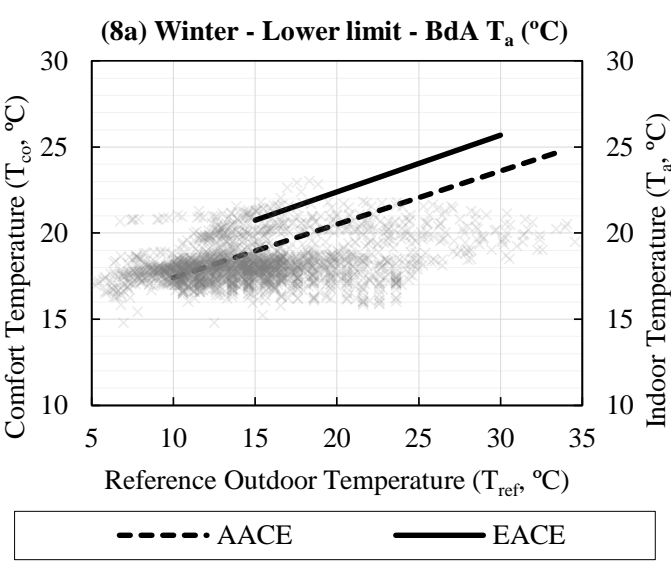

(8c) Summer - Upper limit - BdA $\mathbf{T}_{\mathrm{a}}\left({ }^{\circ} \mathrm{C}\right)$

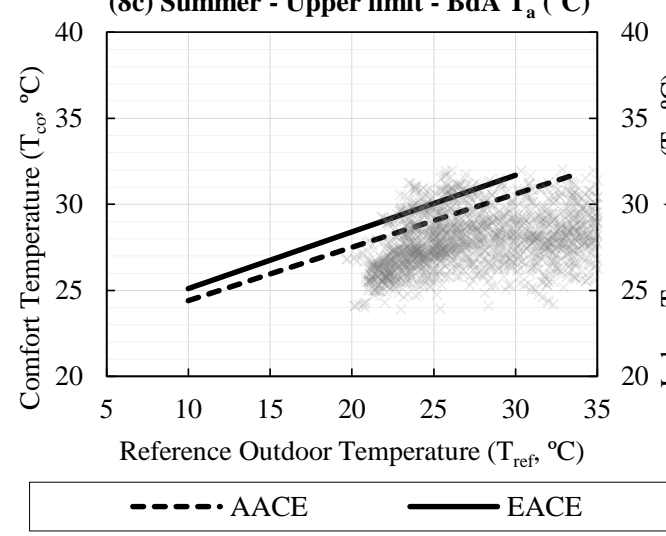

(8b) Winter - Lower limit - LrA T $\left({ }^{\circ} \mathrm{C}\right)$

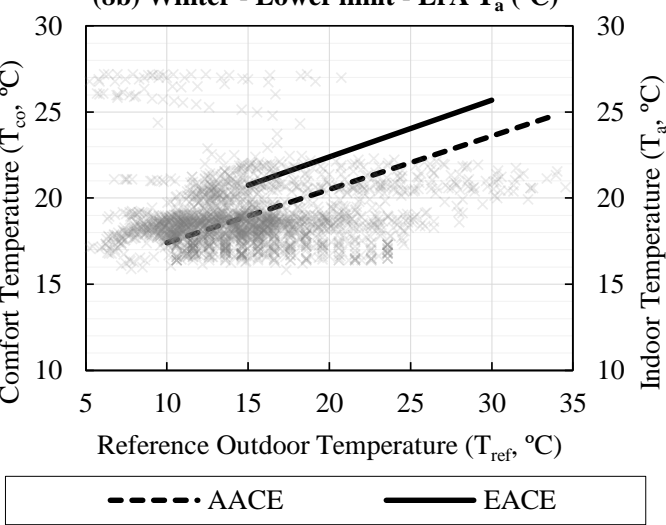

(8d) Summer - Upper limit - $\operatorname{LrA} \mathbf{T}_{\mathrm{a}}\left({ }^{\circ} \mathrm{C}\right)$

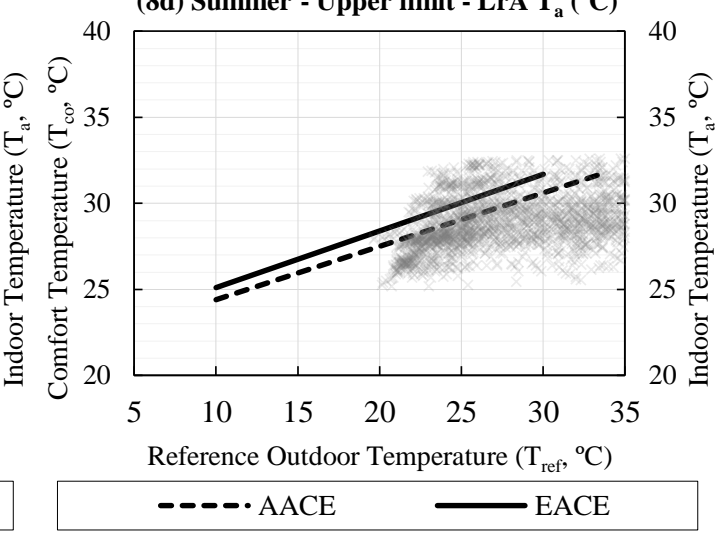

Fig. 8. Comfort-based assessment of monitoring results in BdA (dwelling A bedroom) and LrA (dwelling A living room) using AACE [46] and EACE [47].

To evaluate the lack of comfort in the flats during the monitoring campaign, a discomfort degree-hours estimation has been compiled in Table 7. This reflects the severity of discomfort indoors both when it gets too cold in winter and too warm in summer. On the one hand, EACE sets higher values for comfort temperature, with a lower limit ranging from $20.75^{\circ} \mathrm{C}$ to $26.86{ }^{\circ} \mathrm{C}$, and an upper limit ranging from $25.10{ }^{\circ} \mathrm{C}$ to $31.70{ }^{\circ} \mathrm{C}$, and a narrower set of outdoor temperatures to which it can be applied, ranging from $15{ }^{\circ} \mathrm{C}$ to $30{ }^{\circ} \mathrm{C}$. On the other, AACE's lower limit ranges from $17.40{ }^{\circ} \mathrm{C}$ to $24.69{ }^{\circ} \mathrm{C}$ with an upper limit of $24.40{ }^{\circ} \mathrm{C}$ to $31.69{ }^{\circ} \mathrm{C}$, considered trustworthy when applied to outdoor temperatures ranging from $10{ }^{\circ} \mathrm{C}$ to $33.5{ }^{\circ} \mathrm{C}$. In order to understand the figures in Table 7, discomfort degree-hours of heating are associated to the winter period, while those of cooling 
are associated to the summer period. Due to the different ranges of application of both indexes, the level of discomfort in winter is around five times greater according to EACE than according to AACE, whereas EACE seems to be more forgiving than AACE in summer (Table 7) (Figs. 6, 7 and 8). These differences also stress the importance of the outdoor temperature of reference which plays a role in the calculation of comfort ranges. In fact, EACE sets a minimum comfort temperature above $20^{\circ} \mathrm{C}$ during the cold period when the outdoor temperature of reference remains below $15^{\circ} \mathrm{C}$, drawing an almost constant lower limit of comfort temperature most of the time (Fig. 7). In addition, the fact that EACE relies on a running value of reference temperature makes it extremely sensitive to high fluctuations of outdoor conditions, while the reliability of AACE increases as it is based on the prevailing reference temperature (Section 2.7). It can be observed that for outdoor reference temperatures above $30^{\circ} \mathrm{C}$ the EACE estimates higher values of comfort, which in fact is what limits the application of the adaptive model to very hot climates (Figs. 8c and 8d) (Table 6). In contrast, EACE establishes a narrower range of comfort in winter in line with its applicability (Figs. $8 \mathrm{a}$ and 8b).

\begin{tabular}{lcccccc}
\hline & \multicolumn{3}{c}{ AACE } & \multicolumn{3}{c}{ EACE } \\
\hline & BdA & LrA & DwA & BdA & LrA & DwA \\
\hline DDH Heating & 1.45 & 0.94 & 1.11 & 5.74 & 4.67 & 5.09 \\
DDH $_{\text {Cooling }}$ & 5.28 & 7.26 & 6.24 & 3.92 & 5.74 & 4.80 \\
\hline
\end{tabular}

Table 7. Thousands of discomfort degree-hours of heating (DDHHeating) and cooling (DDHCooling) needs from monitoring results in BdA (dwelling A bedroom), LrA (dwelling A living room) and DwA (dwelling A) according to AACE [46] and EACE [47].

\subsection{Setting energy models}

The process of matching measured and predicted data has a high impact on the reliability of results in later energy assessment. This is one of the major targets of long-term monitoring in the case-study flats. Environmental variables which play a part in the energy balance of the case-study models were fine-tuned so that the adjustment of hourly predicted and collected data shared similar trends and the statistical indexes calculated for a period of a month complied with the hourly criteria for calibration (Section 2.5) (Table 8). The inaccurate schedules of users' habits add uncertainty to the adjustment process. Higher NMBE values in summer can be associated with a periodic but occasional use of the split heat pump to instantly cool indoor environments on the hottest days, and the inaccuracy of the schedule of natural ventilation of real users, which entails an error accumulation, making it difficult to adjust both temperature trends exactly. Besides, in accordance with this, $\mathrm{CV}$ (RMSE) is also elevated, which means that energy models have more difficulties in converging with the overall monitoring data trend. Winter values are affected adversely by the uncontrolled ventilation both by the lack of it or by opening the windows prompting a very sharp reduction in indoor air temperature values. The models were considered reliable thanks to the combination of both graphical and statistical analysis. The former focused on approaching temperature trends while the latter followed the ASHRAE Guideline 14 criteria [40]. After a sensitivity analysis to identify other indicators which may have affected the results, the approach to real conditions was considered sufficient when NMBE and CV(RMSE) values in all cases decreased between $\pm 10 \%$ and below $30 \%$ respectively (Table 8) [40].

\begin{tabular}{cccccccc}
\hline & \multicolumn{3}{c}{ Winter } & \multicolumn{3}{c}{ Summer } & \multirow{2}{*}{$\begin{array}{c}\text { ASHRAE Guideline 14 } \\
\text { Hourly criteria }\end{array}$} \\
\hline & BdA & LrA & DwA & BdA & LrA & DwA & \pm 10 \\
NMBE (\%) & -4.04 & 2.57 & 3.62 & -8.41 & -7.28 & -7.06 & 30 \\
CV(RMSE) (\%) & 6.89 & 4.35 & 5.59 & 8.90 & 7.96 & 8.27 & \\
\hline
\end{tabular}

Table 8. Validation of hourly adjustment of energy models according to ASHRAE Guideline 14 [40]. BdA (dwelling A bedroom), LrA (dwelling A living room) and DwA (dwelling A). 


\subsection{Proposal of improvement}

\section{- Sensitivity analysis: impact on energy demand and thermal comfort}

Prior to configuring the all-inclusive proposal, strategies were tested in a whole-flat model positioned in the different orientations where real case-study flats are.

A sensitivity analysis is run to see what the energy profits associated to occasional action are (Fig. 9). Reducing the permeability of the windows $\left(\mathrm{H}_{\mathrm{V} 1}\right)$ boosts the highest overall demand reductions due to a major decrease in heating demand. Over 30\% reduction in heating demand is observed in the north-oriented flats while almost $40 \%$ can be seen in the south-oriented one; cooling demand decreases by $8 \%$ in all cases, which added to the energy saving in heating demand, leads to a reduction in global demand of almost $24 \%$ and $28 \%$ in north- and southoriented flats, respectively (Fig. 9). Subsequently, adding thermal insulation $\left(\mathrm{H}_{\mathrm{TI}}\right)$ considerably reduces energy demand too. These reductions are more pronounced in north-oriented apartments, with a decrease of around $13 \%$ in global demand, while in south-oriented apartments this figure remains around $10 \%$ (Fig. 9). Regarding the low-glazing surface of the case-study flats, around $12 \%$ of the whole façade in all cases, modifying window Uvalues and SHGCs $\left(\mathrm{H}_{\mathrm{VG}}\right)$ contributes slightly to energy saving, since reductions remain below $4 \%$ in all cases (Fig. 9). Last but not least, it is observed that implementing the flats with a more controlled ventilation $\left(\mathrm{H}_{\mathrm{V} 1+\mathrm{V} 2}\right.$ and $\mathrm{H}_{\mathrm{V} 1+\mathrm{V} 2+\mathrm{R}}$ ) works similarly in all three cases. This condition contributes to better indoor air quality than relying on air renewal through the manual opening of windows. Nevertheless, the sole consideration of a controlled ventilation system without heat-recovery $\left(\mathrm{H}_{\mathrm{V} 1+\mathrm{V} 2}\right)$, relying on a constant air supply by mechanical ventilation only substituted by natural ventilation on summer nights (Section 2.6.2) increases heating demand by around $4 \%$, although generally reduces cooling demand by $11 \%$ and overall demand by less than $1 \%$. Therefore, upgrading this last plan of action with a heat recovery system $\left(\mathrm{H}_{\mathrm{V} 1+\mathrm{V} 2+\mathrm{R}}\right)$ eases heating demand, which decreases by 1 to $1.3 \%$, cooling demand by around $14 \%$ and eventually overall demand by 5 to $6 \%$ (Fig. 9).

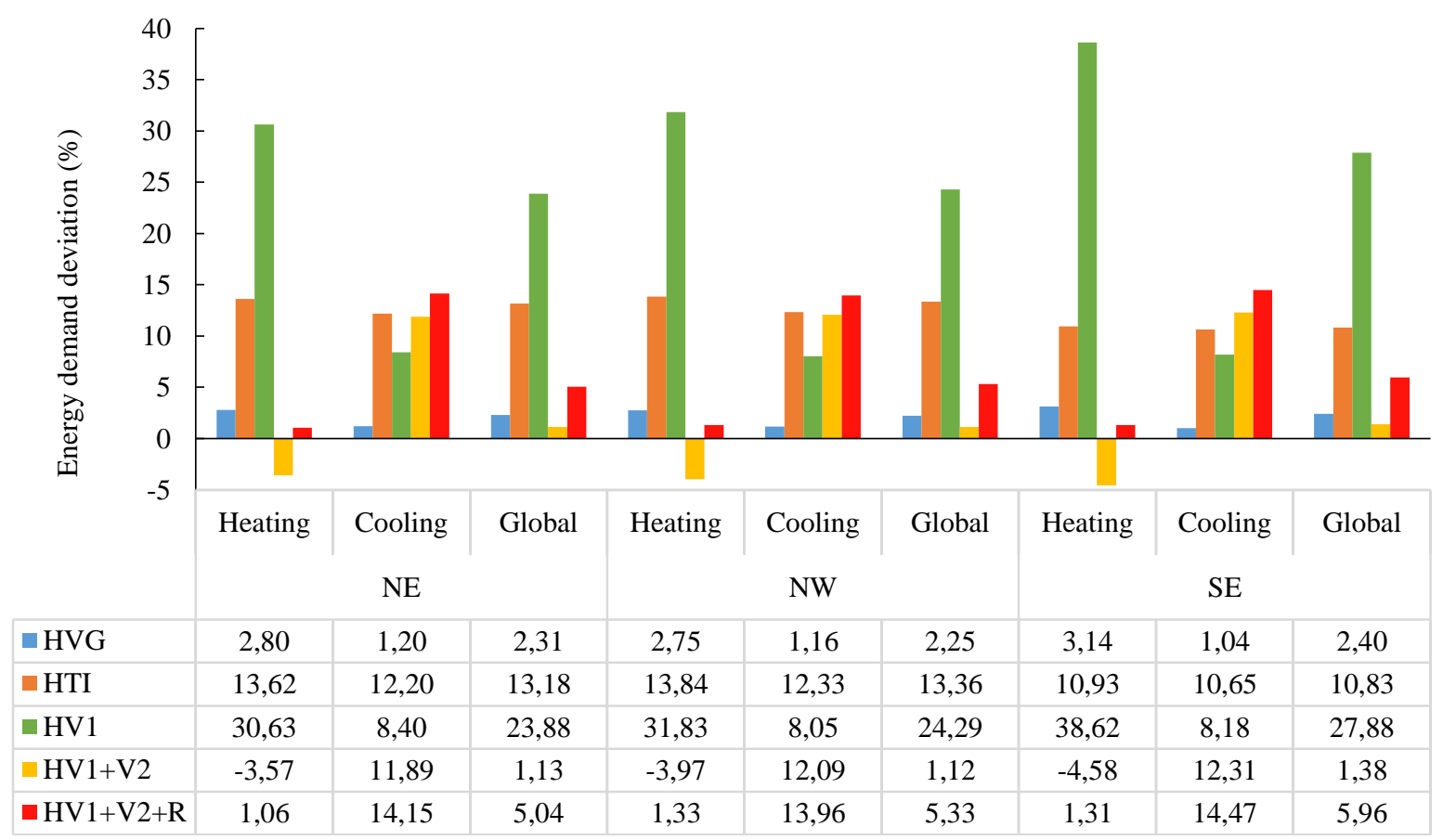

Fig. 9. Energy demand deviation (\%) of the hypotheses tested on the Base Case.

According to the aim of the paper, the suggested strategies should be carefully assessed providing they do not compromise the thermal wellbeing of users and boost energy savings. In order to see whether they also have good impact on indoor comfort conditions, a second sensitivity analysis is run to see the extent to which they can decrease discomfort degree-hours (Section 2.7). Implicitly, results from the analysis displayed in Figure 10 will show the validity of a refurbishment action to diminish the number of hours where indoor conditions are outside 
the comfort ranges, as well as the amount of degrees by which indoor temperatures fall outside the comfort range, approaching comfort limits. Hence, fewer hours of discomfort will lead to less need and use of HVAC systems and in turn, a lower energy demand. As mentioned in Section 3.1, discomfort degree-hours of heating and cooling are associated to the winter and the summer periods, respectively. Figure 10 displays the deviation of discomfort degree hours based on the ACEs considered (Section 2.7).

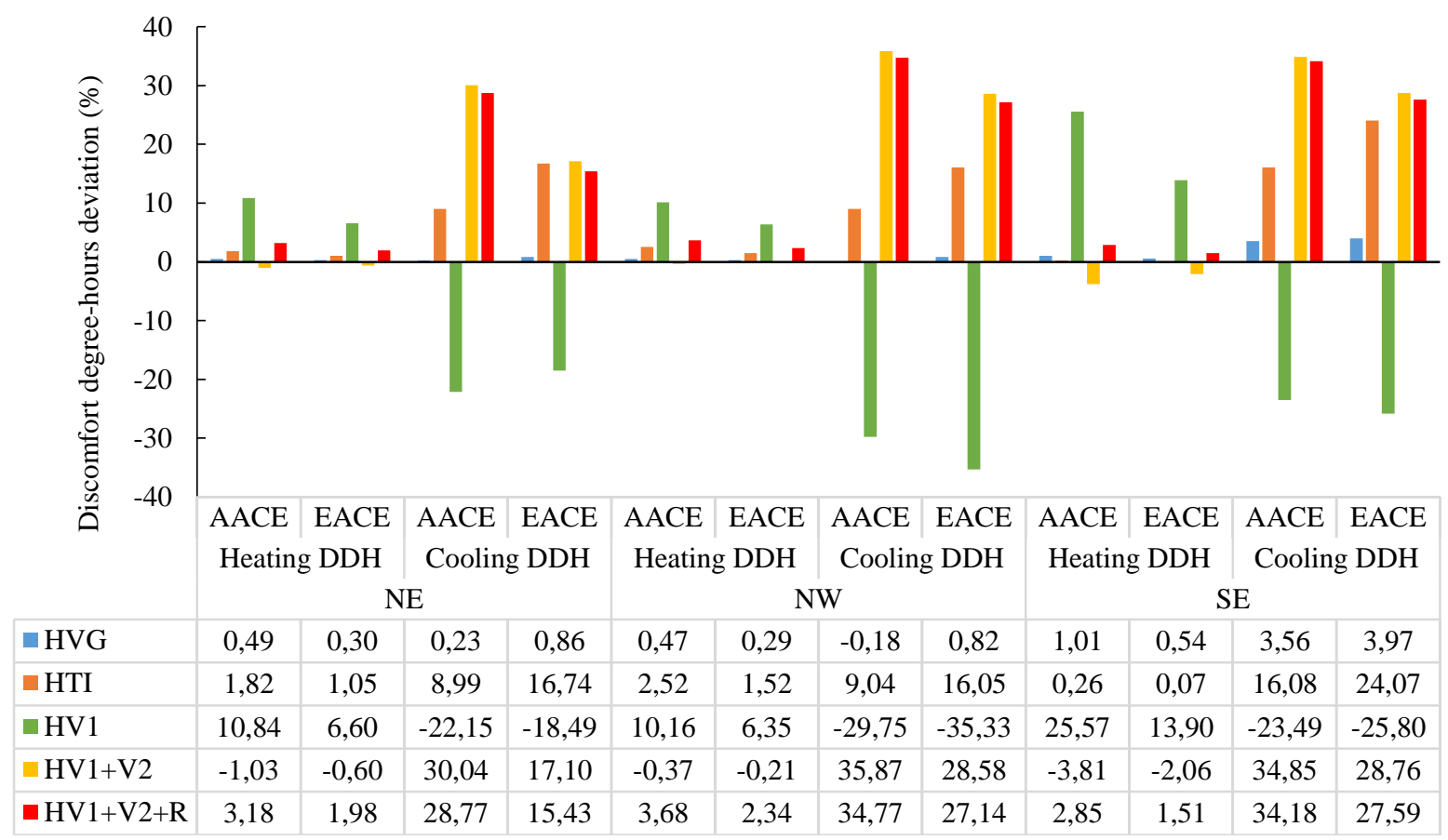

Fig. 10. Discomfort degree-hours deviation (\%) of the hypotheses tested on the Base Case, according to AACE [46] and EACE [47].

In general, correlations with energy demand deviations shown in Figure 9 can also be observed in Figure 10, starting with the hypothesis of variable glazing $\left(\mathrm{H}_{\mathrm{VG}}\right)$, which in general, has the lowest impact on indoor conditions. Solar control properties of the glazing mostly benefit indoor comfort of southern orientations during summer, when the maximum deviations are displayed in Figure 10: the amount of time in which discomfort is meant to be countered with the use of cooling is reduced by around $4 \%$ according to both ACEs, whereas that linked to the use of heating devices is reduced by $0.54 \%$ according to EACE and to $1.01 \%$ according to AACE. Mediterranean weather conditions on warm days severely affect indoor conditions due to the high solar gains, which mostly affect southern orientations. At the same time, there is barely any impact of solar gains on northoriented flats and - as opposed to winter - the decrease in discomfort does not reach $0.9 \%$ in any case during summer.

In line with the figures included in Figure 10, the hypothesis adding thermal insulation $\left(\mathrm{H}_{\mathrm{TI}}\right)$ reduces summer indoor discomfort by around $10 \%$ in northern cases and by $16 \%$ in southern cases, according to AACE, whereas EACE sets these numbers around $16-17 \%$ in northern cases and $24 \%$ in southern cases. In winter, deviations caused by $\mathrm{H}_{\mathrm{TI}}$ rise by almost $1-2.5 \%$ in the north-oriented flats, while this increase is around $0.3 \%$ in the case of the south-oriented ones. Conversely, although strategy $\mathrm{H}_{\mathrm{v} 1}$ shows a better performance of the flats in winter, it worsens considerably discomfort in summer. AACE sets higher deviations of heating DDH which are almost double those established by EACE. In winter, the decrease in discomfort is more significant in the south-oriented flat (up to $25.57 \%$ according to AACE and $13.90 \%$ according to EACE) while in the north-oriented ones it remains at around $10 \%$, according to AACE, and 6.50\%, according to EACE (Fig. 10). As a result of increasing air-tightness in the flat, negative values reflect increased discomfort in summer in all cases, rising from 18.50 to $25.80 \%$ according to AACE, and from 22.15 to $23.49 \%$ according to EACE, in the eastern orientations (Fig. 10). In the case of western orientations these figures respectively increase to $29.75 \%$, according to AACE, and $35.33 \%$ according to EACE (Fig. 10). This should be noted as thermal insulation is commonly thought to 
significantly improve energy performance in winter, despite the fact that a layer of thermal insulation of just 2 $\mathrm{cm}$ is not enough to fight against winter energy losses, mostly due to air-leakages from the flat. In line with the need to fight against uncontrolled air-flow through the unsealed parts of the façades, these two actions, namely $\mathrm{H}_{\mathrm{TI}}$ and $\mathrm{H}_{\mathrm{V} 1}$, are bound to complement each other.

Eventually, the idea of decreasing the permeability of the façade which widely benefits indoor conditions during winter must go hand-in-hand with another summer-favourable strategy, that of a controlled ventilation system. The addition of a natural ventilation rate in summer during the night, helps to reduce overheating processes by $30.04 \%$ in NE, $35.87 \%$ in NW and $34.85 \%$ in SE orientations, according to AACE, and $17.10 \%$ in NE and $28.58 \%$ in NW and $28.76 \%$ in SE orientations, according to EACE (Fig. 10). However, similarly to the energy demand figures (Fig. 9), the mechanical ventilation strategy by itself $\left(\mathrm{H}_{\mathrm{V} 1+\mathrm{V} 2}\right)$ provides an increase in discomfort in winter, $0.21-0.37 \%$ in $\mathrm{NW}, 0.6-1.03 \%$ in $\mathrm{NE}$ and $2.06-3.81 \%$ in SE, according to EACE and AACE, respectively (Fig. 10). This is the reason why the last hypothesis $\left(\mathrm{H}_{\mathrm{V} 1+\mathrm{V} 2+\mathrm{R}}\right)$ was taken into consideration, given that implementing mechanical ventilation with a heat recovery system increases indoor comfort both in winter and summer. In all cases the data reflected in Figure 10 show that heating discomfort-hours were lowered by around 1.5-2.34\% according to EACE and around 2.85-3.68\% according to AACE, whereas summer discomfort was reduced by $28.77 \%$ in NE and almost $35 \%$ in NW and SE orientations, according to AACE, and by $15.43 \%$ in NE and almost $27 \%$ in NW and SE orientations, according to EACE.

In order to summarize the benefits and drawbacks of each hypothesis, the following ideas are set out as guidelines for thermal comfort improvement and energy saving:

- The strategies based on implementing window glazing with improved characteristics $\left(\mathrm{H}_{\mathrm{VG}}\right)$ such as solar control or low emissive properties, together with more air-tight window joinery, can definitely contribute to preventing impact on intense solar radiation conditions indoors or can help maintain a warm ambient. However, its effect is barely noticed if the glazing surface is not a significant part of the whole thermal envelope, as in the case in the case-study flats, with only $12 \%$ glazing surface.

- Increasing window air-tightness $\left(\mathrm{H}_{\mathrm{V} 1}\right)$ allows a significant decrease in energy losses reducing façade air-leakages, and favouring and stabilizing indoor conditions. This strategy results in a decrease in overall energy demand, mostly due to less need to turn on the heating systems in winter. Although this highly benefits north-oriented flats during winter, they are also penalized by less solar radiation. In contrast, insulating the building to ensure very steady conditions can aggravate warm environments in summer, making it less comfortable, and worsening indoor air quality.

- Lack of thermal insulation is one of the main drawbacks causing poor energy performance of buildings. Adding an appropriate layer of insulation material (either from the inside or outside) is certain to improve buildings' behaviour in winter. However, when the layer is not thick enough due to architectural constraints (such as heritage protection) this strategy $\left(\mathrm{H}_{\mathrm{TI}}\right)$ may not be as efficient as expected.

- In the event of constructive restrictions such as heritage protection of the building façade, decreasing window permeability $\left(\mathrm{H}_{\mathrm{v}_{1}}\right)$ should be combined with the addition of thermal insulation to the outer walls $\left(\mathrm{H}_{\mathrm{TI}}\right)$ in order to ensure improved results.

- The renovation of indoor air in the case-study flat only happens when the users open the windows and is not sufficient to maintain good quality conditions. Installing a mechanical ventilation system for the constant renovation of indoor air in the flats will further improve global energy performance. However, this mechanism could have negative effects in winter. It could cause energy losses despite increased airtightness from $\mathrm{H}_{\mathrm{V} 1}$ and $\mathrm{H}_{\mathrm{TI}}$, increasing heating needs. For this reason, the implementation of controlled ventilation with a heat recovery system is sure to compensate for a lower energy demand and ensure a better level of wellbeing. 


\section{- Best-Case: global impact of passive strategies}

After assessing the impact of the different strategies separately, current state conditions, assessed on the Base Case, were compared to the overall improved conditions arising from the all-inclusive proposal, implemented on the energy model and becoming the Best Case. On average, indoor temperature results increased by $0.9-1.30{ }^{\circ} \mathrm{C}$ in winter, while they decreased by around $0.30-0.66^{\circ} \mathrm{C}$ in summer (Table 9 ).

\begin{tabular}{ccccccc}
\hline & \multicolumn{3}{c}{ Winter } & \multicolumn{3}{c}{ Summer } \\
\hline & NE & NW & SE & NE & NW & SE \\
\hline BdA & +1.00 & +0.94 & +0.93 & -0.40 & -0.58 & -0.66 \\
LvA & +0.93 & +1.04 & +1.28 & -0.30 & -0.42 & -0.39 \\
DwA & +0.94 & +1.00 & +1.16 & -0.40 & -0.47 & -0.47 \\
\hline
\end{tabular}

Table 9. Averaged variation of indoor temperature $\left({ }^{\circ} \mathrm{C}\right)$. Base Case vs. Best Case.

Figures 11 and 12 display the amount of hours in discomfort calculated in the analysed dwelling (Dwelling A) energy models (Base Case vs. Best Case) according to AACE and EACE (Section 2.7), respectively. In addition, Table 10 presents the deviation of discomfort degree-hours obtained when comparing both energy models. In general, similar discomfort trends can be observed in both pairs of rooms studied. According to AACE (Figure 11 ), the greatest reductions occurred in summer, when indoor discomfort decreased in this order, NE, NW and SE, by around $35.72-39.93 \%$ in the living rooms, by $41.39-44.33 \%$ in the bedrooms and by $42.16-45.54 \%$ in the entire dwelling (Table 10). There was a less notable deviation in winter discomfort, decreasing to around 19.36$22.19 \%$ in the north-oriented spaces and 35.10-40.62\% in the south-oriented ones (Table 10) (Fig. 11). The EACE standard (Fig. 12) seems to be more forgiving during summer, establishing higher levels of comfort and widening the range for users' adaptability. In accordance with EACE, winter indoor discomfort was lowered by around $12.15-13.74 \%$ in the northern rooms and around $18.58-21.03 \%$ in the southern rooms (Table 10) (Fig. 12). However, in summer, the range of discomfort reductions varied widely from $29.38 \%$ in the NE living room to $50.79 \%$ in the SE bedroom (Table 10) (Fig. 12). In the cases of both AACE and EACE, the amount of time in discomfort associated to heating use and that linked to the use of cooling seem to decrease greatly, mostly in the south-oriented bedrooms (Table 10).

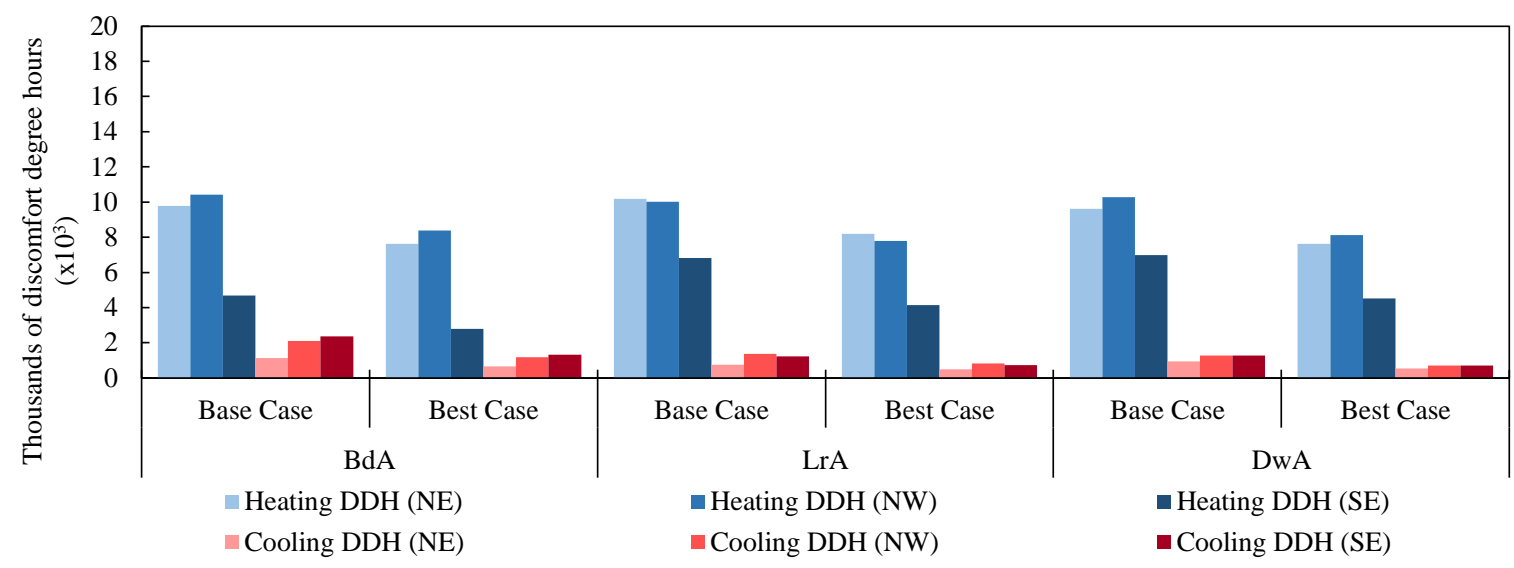

Fig. 11. Thousands of discomfort degree-hours. AACE [46]. Base Case vs. Best Case. BdA (dwelling A bedroom), LrA (dwelling A living room) and DwA (dwelling A). 


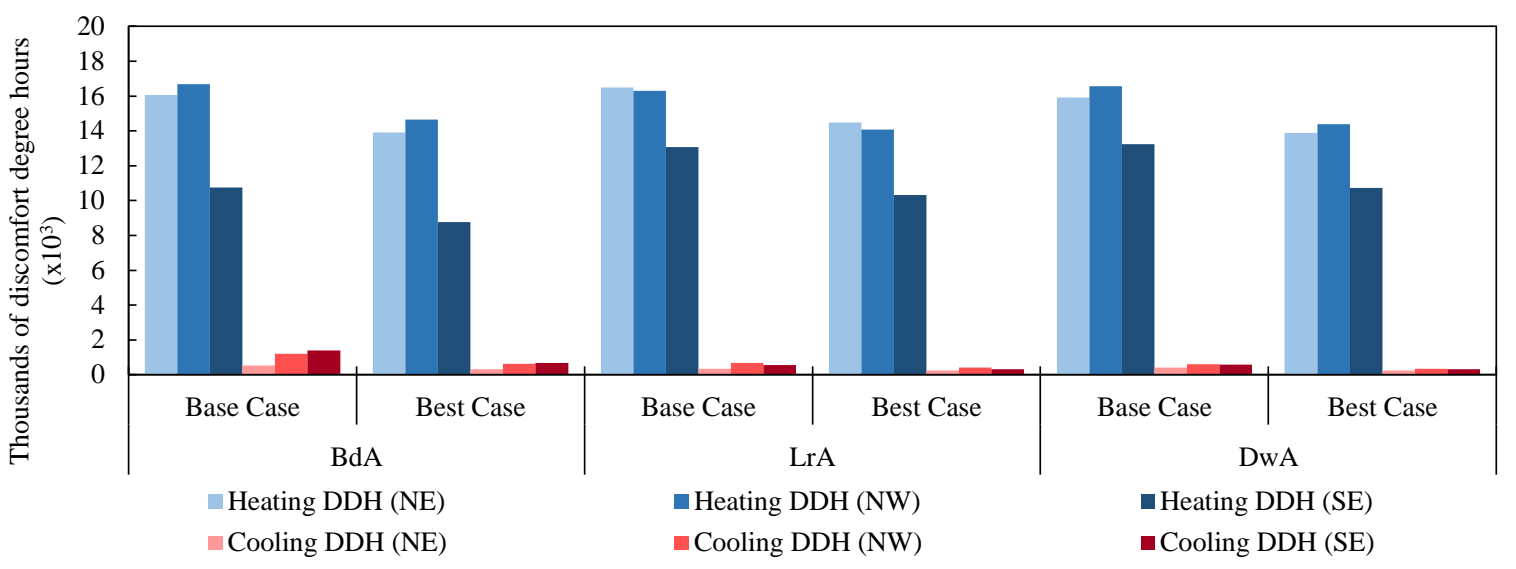

Fig. 12. Thousands of discomfort degree-hours. EACE [47]. Base Case vs. Best Case. BdA (dwelling A bedroom), LrA (dwelling A living room) and DwA (dwelling A).

\begin{tabular}{llcccccc}
\hline & \multicolumn{3}{c}{ AACE } & \multicolumn{3}{c}{ EACE } \\
\hline & & BdA & LrA & DwA & BdA & LrA & DwA \\
\hline \multirow{4}{*}{ DDHH } & NE & 21.97 & 19.67 & 20.84 & 13.45 & 12.24 & 12.68 \\
& NW & 19.36 & 22.19 & 20.95 & 12.15 & 13.74 & 13.09 \\
& SE & 40.62 & 39.17 & 35.10 & 18.58 & 21.03 & 18.88 \\
& NE & 41.39 & 35.72 & 42.16 & 40.64 & 29.38 & 38.40 \\
DDHC & NW & 43.24 & 38.57 & 44.26 & 47.46 & 36.52 & 43.35 \\
& SE & 44.33 & 39.93 & 45.54 & 50.79 & 41.50 & 47.83 \\
\hline
\end{tabular}

Table 10. Discomfort degree-hours deviation (\%) according to AACE [46] and EACE [47]. Base Case vs. Best Case. BdA (dwelling A bedroom), LrA (dwelling A living room) and DwA (dwelling A).

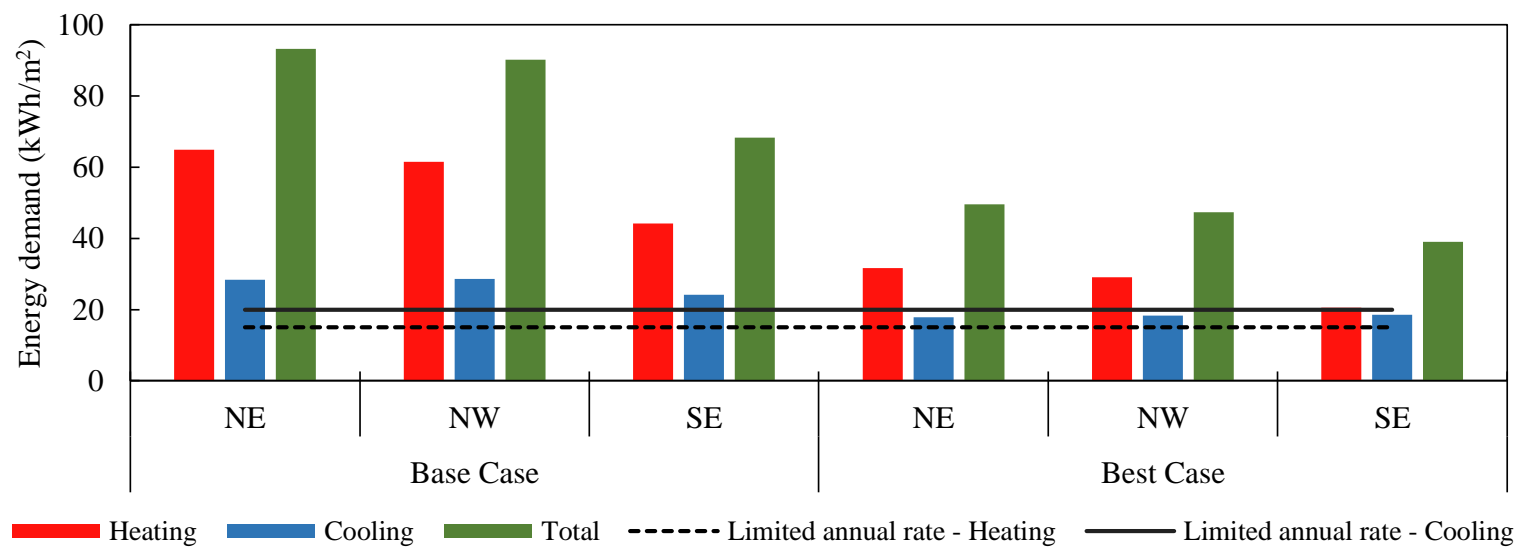

Fig. 13. Annual energy demand $\left(\mathrm{kWh} / \mathrm{m}^{2}\right)$ comparison. Base Case vs. Best Case.

\begin{tabular}{lccc}
\hline & $E_{\text {Heating }}$ & $E_{\text {Cooling }}$ & E $_{\text {Global }}$ \\
\hline $\mathrm{NE}$ & $51.26 \%$ & $36.98 \%$ & $46.92 \%$ \\
$\mathrm{NW}$ & $52.69 \%$ & $36.16 \%$ & $47.45 \%$ \\
$\mathrm{SE}$ & $53.67 \%$ & $23.12 \%$ & $42.89 \%$ \\
\hline
\end{tabular}

Table 11. Annual energy demand deviation (\%). Base Case vs. Best Case. 
Figure 13 shows the heating, cooling and global energy demands calculated for the whole dwelling in Base Case and Best Case. To complement these results, Table 11 offers the annual energy demand deviation following the application of the all-inclusive proposal. The Spanish Code for conventional buildings sets a $15 \mathrm{kWh} / \mathrm{m}^{2}$ and 20 $\mathrm{kWh} / \mathrm{m}^{2}$ annual rate for heating and cooling demands, respectively [31]. Although significant reductions of around $50 \%$ are observed in heating demand in all cases (Table 11), with figures set at around $30 \mathrm{kWh} / \mathrm{m}^{2}$ in the northern orientations and $20 \mathrm{kWh} / \mathrm{m}^{2}$ in the southern ones (Fig. 13), these are not enough to comply with conventional requirements. In the meantime, thanks to the refurbishment proposal, cooling demand results decrease by $20-35 \%$ (Table 11) and remain below the aforementioned standard (around $18 \mathrm{kWh} / \mathrm{m}^{2}$ ) (Fig. 13). $\mathrm{Be}$ that as it may, the energy updating and implementation of this type of protected buildings should seek a reduction in annual energy demand, as long as comfort conditions are significantly improved and not compromised. The retrofit proposal offers an important enhancement of the quality of indoor conditions and highlights the potential for energy saving in this type of buildings.

\section{Conclusions}

A large part of the Mediterranean housing buildings needs to be updated in terms of energy efficiency. Some of these present architectural characteristics to be preserved according to local heritage regulations. Hence the need for these refurbishments to seek balanced interventions is what makes the process more complex.

An all-inclusive proposal regarding the modification of window joinery and glazing, ventilation and thermal insulation of walls is provided. Obviously, the different actions do not provide equal benefits in local winter and summer conditions. Hypotheses contemplating higher levels of air-tightness and the addition of thermal insulation result in the highest reductions in global energy demand (around 24-28\% and 10-13\% respectively). Indoor comfort is also increased with thermal insulation in both summer (10-16\% according to AACE; 16-25\% according to EACE) and winter (0.3-2.5\%). However, decreasing permeability only benefits winter comfort (6$10 \%$ and $13-25 \%$ for north- and south-oriented flats respectively) while it increases discomfort in summer in all cases (around 18-35\%). These results demonstrate the need for a forced air ventilation plan of action that provides better air quality, while there is also a need for heating recovery in order to avoid an increase in winter energy demand. This hypothesis results in a 5-6\% decrease in global energy demand, 1-1.3\% in heating demand and $14 \%$ in cooling demand, with comfort conditions slightly upgraded in winter (barely 1.5-3\%) and a more notable improvement in summer (30-35\% according to AACE; 15-27\% according to EACE). These strategies are certainly in keeping with the ever-changing possibilities on offer from heritage buildings.

As a guideline, the benefits and drawbacks of the retrofit strategies considered can be summarized as follows. The change of window glazing characteristics alone is highly dependent on the total glazing surface to ensure noticeable impact on the global energy balance. In contrast, increased thermal envelope air-tightness using less permeable window joinery and the addition of an insulation layer can help counter energy losses, while helping improve wellbeing in colder periods. In order to ensure continuous air supply and renovation to improve indoor air quality, and boost heat dissipation in the warm season sealing the outer walls must be combined with a controlled ventilation system. The mechanical ventilation must incorporate heat recovery to make up for energy needs and avoid forcing energy losses by means of constant air change.

Comfort-based assessments following adaptive standards are presented as a more certain approach to the real performance of buildings. The use of a weighted mean temperature as outdoor reference temperature brings about a more accurate analysis of the impact of local conditions on thermal experience. Considering the range of the two equations calculated for the case study context, the EACE provides a wider adaptability in summer (on average $0.90^{\circ} \mathrm{C}$ more) but its application can be considered only up to $30^{\circ} \mathrm{C}$ of outdoor temperature, while the AACE shows greater tolerance in winter (on average $2.10^{\circ} \mathrm{C}$ less). In summer it can be adopted up to $33.5^{\circ} \mathrm{C}$ of outdoor temperature, more suitable to the severe conditions of the considered climate.

Therefore, the American index, due to its wider range of applicability, is better suited to the southern Spanish context than the European one. However, in order to address thermal comfort in buildings, the fact that adaptive approaches rely on the outdoor weather conditions and the user's adaptability, a thorough analysis is required for 
individual cases so that a valid adaptive comfort equation can be established. Further research on collecting indoor conditions, surveys on user habits and current energy performance of residential and heritage buildings located under Mediterranean climate is needed to bridge this gap.

In general, the reduction in global energy demand for all the orientations (47\% lower at most) is more noticeable than the improvement in comfort conditions, which varies $20-40 \%$ in winter and $35-50 \%$ in summer, according to AACE, and differs by $12-21 \%$ in winter and $29-50 \%$ in summer, according to EACE.

The refurbishment strategy for these protected buildings has led to indoor conditions almost complying with Spanish Code energy requirements provided for conventional buildings, shortening annual global demand and ensuring that cooling remains below the upper limit.

\section{References}

[1] European Commission. Report from the Commision to the European Parliament and the Council - Progress by Member States in reaching cost-optimal levels of minimum energy performance requirements 2016.

[2] European Commission. Directive EU 2018/844 of the European Parliament and of the Council of 30 May 2018 amending Directive 2010/31/EU on the energy performance of buildings and Directive 2012/27/EU on energy efficiency. Off J Eur Union 2018:75-91.

[3] Buceti G. Climate change and vulnerabilities of the European energy balance. Sustain Dev Energy Water Environ Syst 2015;3:106-17. doi:10.13044/j.sdewes.2015.03.0008.

[4] López-Ochoa LM, Las-Heras-Casas J, López-González LM, Olasolo-Alonso P. Environmental and energy impact of the EPBD in residential buildings in hot and temperate Mediterranean zones: The case of Spain. Energy 2018;161:618-34. doi:10.1016/J.ENERGY.2018.07.104.

[5] Martínez-Molina A, Tort-Ausina I, Cho S, Vivancos J-L. Energy efficiency and thermal comfort in historic buildings: A review. Renew Sustain Energy Rev 2016;61:70-85. doi:10.1016/J.RSER.2016.03.018.

[6] Webb AL. Energy retrofits in historic and traditional buildings: A review of problems and methods. Renew Sustain Energy Rev 2017;77:748-59. doi:10.1016/j.rser.2017.01.145.

[7] Escandón R, Sendra JJ, Suárez R. Energy and climate simulation in the Upper Lawn Pavilion, an experimenta laboratory in the architecture of the Smithsons. Build Simul 2015;8:99-109. doi:10.1007/s12273-014-0197-0.

[8] Napoli G, Bottero M, Ciulla G, Dell'anna F, Figueira JR, Greco S. Energy Retrofit of Public Buildings and Multiple Criteria Decision Aiding: the Application of the Electre Tri-Nc Model to a Decision Process Under Architectural or Landscape Constraints. Digit. Proc. 13th Conf. Sustain. Dev. Energy, Water Environ. Syst., 2018 Sep 30-Oct 4; Palermo, Italy: 2018, p. 0239_1-18.

[9] Mazzola E, Dalla Mora T, Peron F, Romagnoni P. The application of an integrated energy and environmental audit process on historic building. Digit. Proc. 13th Conf. Sustain. Dev. Energy, Water Environ. Syst., 2018 Sep 30-Oct 4; Palermo, Italy: 2018, p. 0439_1-13.

[10] Escandón R, Suárez R, Sendra JJ. On the assessment of the energy performance and environmental behaviour of social housing stock for the adjustment between simulated and measured data: The case of mild winters in the Mediterranean climate of southern Europe. Energy Build 2017;152:418-33. doi:10.1016/j.enbuild.2017.07.063.

[11] Raja IA, Nicol JF, McCartney KJ, Humphreys MA. Thermal comfort: Use of controls in naturally ventilated buildings. Energy Build 2001;33:235-44. doi:10.1016/S0378-7788(00)00087-6.

[12] Lucchi E. Preservation of Heritage, Environmental Quality and Energy Efficiency: the Retrofit Actions of a Residential Quarter in Milan. Perspect. Contemp. y Nuovas Dimens. del Patrim., 2010, p. 703-10.

[13] Singh MK, Attia S, Mahapatra S, Teller J. Assessment of thermal comfort in existing pre-1945 residential building stock. Energy 2016;98:122-34. doi:10.1016/j.energy.2016.01.030.

[14] Sendra JJ, Domínguez-Amarillo S, Bustamante P, León a. L. Energy intervention in the residential sector in the south of Spain: Current challenges. Inf Constr 2014;65:457-64. doi:10.3989/ic.13.074.

[15] Suárez R, Fernández-Agüera J. Passive energy strategies in the retrofitting of the residential sector: A practical case study in dry hot climate. Build Simul 2015;8:593-602. doi:10.1007/s12273-015-0234-7.

[16] Ealiwa MA, Taki AH, Howarth AT, Seden MR. An investigation into thermal comfort in the summer season of Ghadames, Libya. Build Environ 2001;36:231-7. doi:10.1016/S0360-1323(99)00071-2. 
[17] Cantin R, Burgholzer J, Guarracino G, Moujalled B, Tamelikecht S, Royet BG. Field assessment of thermal behaviour of historical dwellings in France. Build Environ 2010;45:473-84. doi:10.1016/J.BUILDENV.2009.07.010.

[18] Tadeu S, Rodrigues C, Tadeu A, Freire F, Simões N. Energy retrofit of historic buildings: Environmental assessment of cost-optimal solutions. J Build Eng 2015;4:167-76. doi:10.1016/j.jobe.2015.09.009.

[19] Mazzarella L. Energy retrofit of historic and existing buildings. the legislative and regulatory point of view. Energy Build 2015;95:23-31. doi:10.1016/j.enbuild.2014.10.073.

[20] Agencia Estatal. NBE-CT-79 Norma Básica de la Edificación sobre Condiciones Térmicas de los edificios. 1979.

[21] National Statistics Institute (NSI). Population and Housing Census 2011.

www.ine.es/en/censos2011_datos/cen11_datos_inicio_en.htm\%0D (accessed November 8, 2018).

[22] Asociación Española de Normalización y Certificación (AENOR). UNE-EN ISO 7730 Ergonomía del ambiente térmico. Determinación analítica e interpretación del bienestar térmico mediante el cálculo de los índices PMV y PPD y los criterios de bienestar térmico local. 2006.

[23] Fanger PO. Thermal environment - Human requirements. Environmentalist 1986;6:275. doi:https://doi.org/10.1007/BF02238059.

[24] McGilligan C, Natarajan S, Nikolopoulou M. Adaptive comfort degree-days: A metric to compare adaptive comfort standards and estimate changes in energy consumption for future UK climates. Energy Build 2011;43:2767-78. doi:10.1016/j.enbuild.2011.06.037.

[25] Ferrari S, Zanotto V. Thermal comfort approaches and building performance. Build. Energy Perform. Assess. South. Eur. 1st ed., Cham: Springer International Publishing; 2016, p. 47-60. doi:10.1007/978-3-319-24136-4_4.

[26] Blázquez T, Suárez R, Sendra JJ. Monitoring a Pre-Normative Multi-Family Housing Case-Study in a Mediterranean Climate. Buildings 2016;7:1. doi:10.3390/buildings7010001.

[27] Blázquez T, Suárez R, Sendra JJ. Towards a calibration of building energy models: A case study from the Spanish housing stock in the Mediterranean climate. Inf Constr 2015;67. doi:10.3989/ic.15.081.

[28] Docomomo Ibérico Foundation. Documentation and Conservation of the Architecture and Urbanism of the Modern Movement 2013. http://www.docomomoiberico.com/index.php?option=com_k2\&view=item\&id=1008:conjunto-deviviendas-la-estrella\&lang=en (accessed November 8, 2018).

[29] Junta de Andalucía. Instituto Andaluz de Patrimonio Histórico (IAPH). Consejería de Cultura n.d. https://www.iaph.es/patrimonio-inmueble-andalucia/resumen.do?id=i17217 (accessed November 8, 2018).

[30] Mosquera-Adell E, Pérez-Cano MT, Consejería de Obras Públicas y Transportes, Dirección General de Arquitectura y Vivienda. La vanguardia imposible: quince visiones de arquitectura contemporánea andaluza. Consejería. Sevilla: Consejería de Obras Públicas y Transportes; 1990.

[31] Ministerio de Vivienda. Código Técnico de la Edificación (CTE) Documento Básico de Ahorro de Energía (DBHE). 2017.

[32] Kottek M, Grieser J, Beck C, Rudolf B, Rubel F. World Map of the Köppen-Geiger climate classification updated Meteorol Zeitschrift 2006;15:259-63. doi:10.1127/0941-2948/2006/0130.

[33] Agencia Estatal de Meteorología (AEMET). Standard Climate Values - Sevilla Airport n.d. http://www.aemet.es/en/serviciosclimaticos/datosclimatologicos/valoresclimatologicos?k=and (accessed November 8, 2018).

[34] International Organization for Standardization (ISO). ISO 9972: 2006 Thermal performance of buildings Determination of air permeability of buildings - Fan pressurization method. 2006. doi:10.1111/j.13652141.1990.tb07834.x.

[35] (ISO) IO for S. ISO 52016-1:2017. Energy performance of buildings - Energy needs for heating and cooling, internal temperatures and sensible and latent heat loads. 2017.

[36] Fernández-Agüera J, Domínguez-Amarillo S, Sendra JJ, Suárez R. An approach to modelling envelope airtightness in multi-family social housing in Mediterranean Europe based on the situation in Spain. Energy Build 2016;128:236-53. doi:10.1016/j.enbuild.2016.06.074.

[37] International Organization for Standardization (ISO). ISO 7726:1998 Preview Ergonomics of the thermal environment -- Instruments for measuring physical quantities. 2012.

[38] Cipriano J, Mor G, Chemisana D, Pérez D, Gamboa G, Cipriano X. Evaluation of a multi-stage guided search approach for the calibration of building energy simulation models. Energy Build 2015;87:370-85. 
doi:10.1016/J.ENBUILD.2014.08.052.

[39] Zheng O, Eisenhower B. Leveraging the analysis of parametric uncertainty for building energy model calibration. Build Simul 2013;6:365-77. doi:10.1007/s12273-013-0125-8.

[40] American Society of Heating Ventilating and Air Conditioning Engineers (ASHRAE). Guideline 14-2014 Measurement of Energy and Demand Savings. Atlanta, GA, USA: 2014.

[41] Ruiz GR, Bandera CF. Validation of calibrated energy models: Common errors. Energies 2017;10. doi:10.3390/en10101587.

[42] Instituto Eduardo Torroja de Ciencias de la Construcción, CEPCO, AICIA. Constructive Elements Catalogue. vol. 3. Madrid: 2010. doi:10.1099/vir.0.069914-0.

[43] Spanish Asociation of Normalization (AENOR). UNE-EN 12207 Windows and doors - Air permeability Classification. Madrid: 2017.

[44] Ministerio de Vivienda. Código Técnico de la Edificación (CTE) Documento Básico de Salubridad (DB-HS). 2017.

[45] Ferrari S, Zanotto V. Adaptive comfort: Analysis and application of the main indices. Build Environ 2012;49:25-32. doi:10.1016/J.BUILDENV.2011.08.022.

[46] American Society of Heating Ventilating and Air Conditioning Engineers (ASHRAE). ANSI/ASHRAE Standard 55 -2017. Atlanta, GA, USA: 2017.

[47] Asociación Española de Normalización y Certificación (AENOR). UNE-EN-15251 Parámetros del ambiente interior a considerar para el diseño y la evaluación de la eficiencia energética de edificios incluyendo la calidad del aire interior, condiciones térmicas, iluminación y ruido. 2008.

[48] De Dear RJ, Brager GS, Cooper D. Developing an Adaptive Model of Thermal Comfort and Preference. Final Report ASHRAE RP- 884 1997:34.

[49] Nicol JF, Humphreys MA. Derivation of the adaptive equations for thermal comfort in free-running buildings in European standard EN15251. Build Environ 2010;45:11-7. doi:10.1016/j.buildenv.2008.12.013.

[50] Nicol JF, Humphreys MA. Adaptive thermal comfort and sustainable thermal standards for buildings. Energy Build 2002;34:563-72. doi:10.1016/S0378-7788(02)00006-3.

[51] McCartney KJ, Nicol JF. Developing an adaptive control algorithm for Europe: results of the SCATs Project. Energy Build 2002;34:623.

[52] American Society of Heating Ventilating and Air Conditioning Engineers (ASHRAE). ANSI/ASHRAE Standard 55-2013. vol. 13. Atlanta, GA, USA: 2013. doi:10.1007/s11926-011-0203-9.

[53] Nicol JF. Temperature and adaptive comfort in heated, cooled and free-running dwellings. Build Res Inf 2017;45:730-44. doi:10.1080/09613218.2017.1283922. 